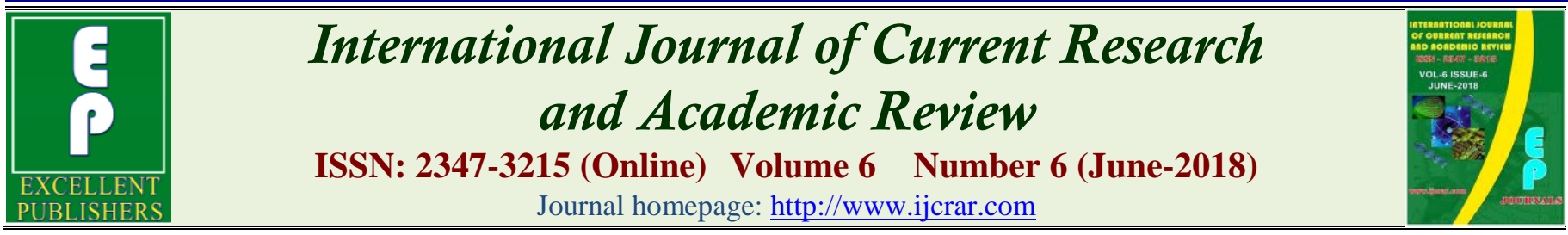

doi: https://doi.org/10.20546/ijcrar.2018.606.004

\title{
In- vitro Anticancer Activity of Berberine alone and in Combination with Epirubicin on Breast Cancer Cells
}

\author{
K.S.V. Prabhu Rathnam ${ }^{1,2}$ and C. Damodara Reddy ${ }^{1}$ * \\ ${ }^{1}$ Sugen Life Sciences Pvt.Ltd. 4/86, S.V.Nagar Perumallapalli, Tirupathi-517502, India \\ ${ }^{2}$ S.V.University, Tirupathi-517502, India
}

*Corresponding author

\section{Abstract}

Herbal medicine is a major form of treatment for more than $70 \%$ of the world's population. At present the use of patent herbal remedies comprised of dried and powdered whole herbs or herbal extracts, besides in tablet form. The study of natural products is multidisciplinary and involves several branches of biological sciences and medicine also. Natural products remain an important source of new structures, and are at the intersection of many fields. Though they may not be the final drug entity, but definitely provides a clue for the desired biological activity. Among several natural or herbal products available, Berberine, a well-known phyto compound has been chosen in the present study to decipher its mechanism of action on breast cancer alone and in combination with Epirubicin. Among the cancer types known to affect, breast cancers are common and in our country, and it's been diagnosed in younger age patients with a poor prognosis. Thus the present study was devised to focus and tap the anti-cancer potential of Berberine alone and in combination with Epirubicin as a new therapeutic entity in the arena. The study was designed using comprehensive cellular and biochemical tools on two different human breast cancer cells namely MCF-7 \& MDA MB 231 and also involved in-silico docking methods. The study results have shown great promise in terms of deciphering the mechanism of action of Berberine alone and in combination with Epirubicin on breast cancer cells. MCF-7 \& MDA MB 231 cells after treatment with Berberine and Epirubicin showed features of apoptosis and also inhibited cell migration. Berberine also showed synergistic chemotherapeutic effect when used in combination with Epirubicin on MCF-7 \& MDA MB 231 cells. The present study provides conclusive evidence for future pre-clinical evaluation of Berberine alone and in combination with Epirubicin befitting and upcoming breast cancer chemotherapeutic agent.
\end{abstract}

\section{Article Info}

Accepted: 28 May 2018

Available Online: 20 June 2018

\section{Keywords}

Berberine, Breast cancer,

Epirubicin, Combination therapy, Synergism.

\section{Introduction}

Natural products offer the best remedies for different disease condition since ancient times. They essentially provide clues for new drug development for several ailments including cancer, diabetes (Torres et al.,
(2012)). Cancers are categorised as chronic diseases and several types have been attributed to life style changes. These include high fat diet, smoking, prolific use of oral contraceptives among several others. Female breast cancer, has presently been stated to be top ranked among Indian population (Malvia et al., (2017)). Recent 
statistical prediction for the year 2020 for Female breast cancer is $17,97,900$ and will significantly impact health budget (Allemani et al., (2018)). Another concern is that the female breast cancers have been diagnosed in younger population and these patients have poor prognosis, in terms of aggressive disease and drug resistant phenotype. In a recently published study in acclaimed journal The Lancet, termed as the CONCORD study, the scenario in India is alarming since the survival rates of breast cancer is poor when compared to several countries ${ }^{4}$. It is in this juncture that the present work was initiated to find new natural product based compounds for effective chemotherapy of breast cancers. A major advantage of natural products based drugs/ compounds, is their excellent safety profile. Based on these premises we hypothesized that Berberine a well-known phyto compound present in several berries and a major constituent in Berberis species may have potent effect on breast cancer cells (Tong et al., (2012)). Present day chemotherapy regimens for breast cancer involve usage of cytotoxic agents which lack tumour cell specificity and hence kill normal cells, resulting in debilitating side effects. With this aspect in mind, we have chosen a well known cancer chemotherapy drug Epirubicin and have studied its anti cancer effects in combination with Berberine. In the present study, we have performed a series of cell biology based assays and determined levels of sensitive molecular markers to ascertain the molecular basis of drug action of Berberine on two well established breast cancer cell lines. In addition to single agent anticancer effect of Berberine, the present study has also determined the mechanism of action of combination chemotherapy of Berberine and Epirubicin and proposes a synergistic mechanism of action, for these two agents on the tested breast cancer cells.

\section{Materials and Methods}

\section{Cell lines and reagents}

MCF-7 and MDA MB 231 cells were obtained from National Centre for Cell Science, Pune, India. MDA MB 231 \& MCF-7 cells were maintained in DMEM high glucose medium supplemented with $10 \%$ Fetal bovine serum (FBS), 100 units $/ \mathrm{mL}$ Penicillin, and $100 \mu \mathrm{g} / \mathrm{mL}$ Streptomycin in an atmosphere of 95\% air and 5\% CO2 at $37^{\circ} \mathrm{C}$.

Berberine (1065210-50MG) and Epirubicin (E9406$5 \mathrm{MG}$ ) were obtained from Sigma-Aldrich. USA. FBS, DMEM, PEN/STREP were purchased from Invitrogen USA. MTT reagent was obtained from SRL; Primary antibodies: mTOR Rabbit mAb (2983- CST), PI3 Kinase p110 $\alpha$ Ab (4255-CST), Bcl2 Ab (2872-CST), BAX Ab (2774-CST), BID Ab (2002-CST), Caspase $3 \mathrm{Ab}$ (ab13586), Caspase $9 \mathrm{Ab}$ (ab32539) and $\beta$-actin (A5441); Secondary antibodies conjugated with HRP were purchased from Santa Cruz (TX, USA); Primers were ordered from Sigma-Aldrich (FH1_BAX, FH1_Bcl2, FH1_CASP3 and FH1_CASP9). All Western-blot related chemicals were purchased from BIO-RAD (CA, USA), Merck (USA); Protease and Phosphatase inhibitors were purchased from Roche (USA). Nitrocellulose membrane for western blot and nylon membrane for EMSA purchased from Amersham. ECL was purchased from BIO-RAD; Trizol (RNAiso plus), cDNA synthesis kit and SYBR green mix were purchased from Takara (Japan). All reagents and chemicals used were of analytical grade.

\section{Cell viability assay}

To ascertain and quantify the cytotoxic activity of Berberine and Epirubicin on breast cancer cells, we performed the 3-(4, 5-dimethylthiazol-2-yl)-2, 5diphenyltetrazolium bromide (MTT) assay, as described previously (Rafehi et al., (2011)).

Briefly, 5000 cells per well (MDA MB-231 \& MCF-7) were plated in 96-well culture plates. After overnight incubation, the cells were treated with varying concentrations of Berberine $(20,40,60,80,100,150,200$ and $300 \mu \mathrm{M}) \&$ Epirubicin $(1,50,100,500 \mathrm{nM}$ and 3, 5, $10 \mu \mathrm{M})$ for 24,48 , and 72 hours with three replicates. Absorbance was recorded at $540 \mathrm{~nm}$ with a reference at $650 \mathrm{~nm}$ serving as the blank. The effect of Berberine on breast cancer cell viability was assessed as percent cell viability compared with vehicle-treated control cells, which were subjectively assigned $100 \%$ viability.

\section{Clonogenic assay}

Equal number of cells were seeded on $65 \mathrm{~mm}$ tissue culture dishes and incubated overnight at $37^{\circ} \mathrm{C}$ in a humidified atmosphere containing $5 \% \quad \mathrm{CO}_{2}$ for cell attachment. Cells were drug treated for $24 \mathrm{~h}$.

Untreated control, positive control and vehicle control were maintained simultaneously. Media change was done periodically. Colonies were fixed, stained and counted (Ahmadiankia et al., (2016)). Plating efficiency and survival fraction was calculated and represented graphically. 
Plating Efficiency $(\%)=\underline{\text { No. of colonies counted }} x 100$

No. of cells seeded

Survival Fraction $=$ No. of colonies counted $\times 100$

No. of cells seeded $\times$ PE of Control

\section{Cell migration assay}

$1.5 \times 10^{5}$ cells were seeded on 6 well plates and incubated overnight at $37^{\circ} \mathrm{C}$ in a humidified atmosphere containing $5 \% \mathrm{CO}_{2}$ for cell attachment. Following treatment with mitomycin-C scratch was induced and cells were drug treated and monitored at $\mathrm{Oh}$ and $24 \mathrm{~h}$ (Chou et al., (2006)). Percentage of migration was calculated and represented graphically.

Percentage of migration $=$

$\underline{\text { Width at } 0 \mathrm{~h}}-\underline{\text { Width at } 24 \mathrm{~h}} \times 100$

Width at $0 \mathrm{~h}$

\section{Combination therapy experiments}

For drug combination experiments (5), cells were treated under 3 different configurations, namely:

$>$ Co treatment with Berberine and Epirubicin for $48 \mathrm{~h}$

$>$ Pre treatment with Berberine for $12 \mathrm{~h}$ followed by Epirubicin for $48 \mathrm{~h}$

$>$ Pre treatment with Epirubicin for $12 \mathrm{~h}$ followed by Berberine for $48 \mathrm{~h}$

Subsequent to the treatments, the plates were processed for MTT assay as described earlier.

Cell viability was measured using MTT method. Briefly, cells were seeded in 96-well plates at a density of 5000 cells per well in $100 \mu \mathrm{l}$ medium. After overnight incubation, increasing concentrations of Berberine or Epirubicin were added to the wells and cultured for $48 \mathrm{~h}$. Then, $10 \mu 1$ of MTT $(0.50 \mathrm{mg} / \mathrm{ml}$ in PBS $)$ was added to the wells and incubated for $4 \mathrm{~h}$ at $37^{\circ} \mathrm{C}$. The mixture was removed and $100 \mu \mathrm{DMSO}$ was added to the wells. The OD values of the wells were detected at $570 \mathrm{~nm}$ by SpectraMax M5 microplate reader (Molecular Devices, USA).

The data were analyzed by CompuSyn software with the results showed in combination index (CI) values, where CI value $<1,=1$, and $>1$ refer to synergetic, additive, and antagonistic effects, respectively (Balakrishna et al., (2015) \& Patil et al., (2010)).

\section{Quantification of gene expression by Real Time PCR}

Cells $\left(1 \times 10^{6}\right)$ were seeded in $100 \mathrm{~mm}$ plates and allowed to attach overnight. Next, cells were treated with Berberine and Epirubicin for 24h.Total RNA was isolated from untreated and treated cells using Trizol reagent. The yield and purity of isolated RNA was checked by UV spectrophotometry. $2 \mu \mathrm{g}$ of total RNA were used in reverse transcription reactions using the $\mathrm{C}$ DNA reverse transcriptase kit according to manufacturer's protocol. Gene expression in untreated and treated cells were determined by real-time PCR using the reverse transcription product, gene-specific primers $(5 \mathrm{pmol})$ and SYBR green in a $20 \mu \mathrm{L}$ reaction volume on the 7500 Fast RT PCR machine (ABI, Carlsbad, CA). Relative changes in mRNA expression levels of genes involved in apoptosis (8) were assessed by the $2-\Delta \Delta C T$ method and changes in mRNA expression of the target gene were normalized to that of GAPDH gene.

Real-time PCR cycle parameters included $10 \mathrm{~min}$ at 95 ${ }^{\circ} \mathrm{C}$ followed by 40 cycles involving denaturation at $95{ }^{\circ} \mathrm{C}$ for $15 \mathrm{~s}$, annealing at $60{ }^{\circ} \mathrm{C}$ for $20 \mathrm{~s}$ and elongation at 72 ${ }^{\circ} \mathrm{C}$ for $20 \mathrm{~s}$. The oligonucleotides used as specific primers (Table 1) for each gene were as follows:

\section{Determination of Apoptotic Protein expression by Immunoblotting}

MDA MB $231 \&$ MCF-7 cells $\left(1 \times 10^{6}\right)$ were seeded in $100 \mathrm{~mm}$ plates and allowed to attach and grow. Upon $80 \%$ confluence of cells were treated with Berberine and Epirubicin. For whole cell protein, lysates were collected using RIPA buffer containing protease/ phosphatase inhibitor cocktail. For nuclear protein, first cytoplasmic extract was collected using buffer A (1M HEPES pH 7.9, 2M KCL,0.5M EDTA pH 8, 0.1M EGTA pH 7, 0.1M DTT, $10 \%$ NP40, protease inhibitor) and later nuclear protein extract were collected using buffer B (1M HEPES pH 7.9, 5M Nacl,0.5M EDTA pH 8, 0.1M

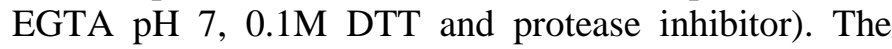
protein concentrations were measured spectrophotometrically using Bio-Rad protein assay kit. Equivalent amounts $(100 \mu \mathrm{g})$ of protein lysates were separated by electrophoresis in $12 \%$ SDS polyacrylamide gel and blotted onto nitrocellulose membrane. The blotted membranes were incubated with primary antibodies for proteins involved in apoptosis pathways. (American cancer society,2011) 
The proteins were visualized using an ECL kit and image acquisition and analysis was performed using Bio Rad Versadoc system.

\section{Statistical analyses}

All experiments were performed using suitable replicates and were repeated three times. IC50 was calculated using Graphpad Prism 6 (GraphPad Software, San Diego, CA) using the observed cell viability values and SEM. For the combination therapy experiments CompuSyn software program was used.

For determining the combination index (CI) for the combination therapy experiments, data is represented as $\mathrm{Fa}$ (Fraction affected). Fa is obtained by calculating the $\%$ viability and subtracting from 100 . The obtained value is divided by 100 to obtain the fraction. Based on the values obtained from the computational analysis, the effects of the drugs used in combination (Berberine \& Epirubicin) is categorised as Synergistic, Additive or Antagonistic effect.

\section{Results and Discussions}

\section{Berberine preferentially inhibits breast cancer cell proliferation}

The effect of Berberine on MDA MB 231 \& MCF-7 cell morphology were evaluated. Phase contrast imaging (Figure $1 \& 2$ respectively) showed that untreated control MDA MB 231 \& MCF-7 cells were epithelial-like adherent cells, with a flat and polygonal shape, that grew homogeneously and showed strong refraction.

When treated with Berberine at $24 \mathrm{~h}, 48 \mathrm{~h} \& 72 \mathrm{~h}$, the cells showed reduced refraction and shrunk to a round shape. The treated cells grew in a scattered way, resulting in loss of intercellular adhesion. The microscope images also showed lot of floating dead cell and debris indicating cytotoxic effect.

\section{Epirubicin treatment induced morphological changes on breast cancer cells}

Epirubicin, a well-known anti-cancer agent, was used in the study and experiments carried out in tandem as above showed that treated MDA MB 231 and MCF-7 cells (Figure $3 \& 4$ respectively) had reduced refraction and shrunk to a round shape, indicating cell death initiation. Epirubicin was extremely cytotoxic at very low nanomolar concentrations.

\section{Berberine inhibited growth of breast cancer cell lines}

To determine the effect of Berberine on the proliferation of BR Cancer cell lines two human cell lines, MDA MB 231 and MCF-7, were treated with varying concentrations of Berberine for 24, 48 and $72 \mathrm{~h}$ and the viable cells were quantitated using the MTT assay. As shown in Figure $1 \& 2$, Berberine inhibited growth of all cell lines in a dose and time-dependent manner. Berberine, however, was more effective in suppressing proliferation of the MDA MB 231 than MCF-7 cells. The IC50s of Berberine for MDA MB 231 at 48 and $72 \mathrm{~h}$ were 21.54 and $10.42 \mu \mathrm{M}$ and those for MCF-7 were 187.9 and $163.1 \mu \mathrm{M}$. (Table 2). Consistent with the cell morphology data as recorded by phase contrast imaging (Figure $1 \&$ 2) showed that Berberine suppressed proliferation and probably triggered cell death pathways and has been aptly confirmed and quantified by the MTT assay.

\section{Epirubicin inhibited growth of breast cancer cell lines}

Epirubicin treatment of the breast cancer cells showed a dose and time dependent cell death and the IC50 of Epirubicin for MDA MB 231 at 48 and $72 \mathrm{~h}$ were 676.6 and $47.53 \mathrm{Nm}$ (Supplementary Figure 3) and those for MCF-7 were 85.2 and $7.69 \mathrm{Nm}$ (Supplementary Figure 4). The MTT data (Table 2) were found to be aligned with the cell morphology recording confirming the cytotoxic effect of Epirubicin.

\section{Effect of Berberine on cell survival}

The most important assay for assessing the anti cancer activity of any drug is the In vitro clonogenic assay. This assay essentially determines the ability or capacity of the cells to divide and produce progenies, i.e. a single cell to form a colony comprising of about 50 cells or more. Drug treated cells are compared with vehicle control treated cells to show the difference in the number of colonies formed and thereby making it feasible to quantify the ability of drugs to inhibit the cell division process.

Treatment of Breast cancer cells MDA MB 231 \& MCF7 cells with various concentrations of Berberine resulted in a concentration dependent decline in the clonogenicity of cells. Results showed a continuous decline in the cell survival with a lowest survival of $8.86 \%$ for $90 \mu \mathrm{M}$ for MCF-7 (Figure 4 \& 5). Whereas for MDA MB 231, a lowest survival of $19.10 \%$ for $20 \mu \mathrm{M}$ was determined (Figure 5, Table 3). Thus the reproductive capability of 
MDA MB 231 \& MCF-7 cells decreased significantly with increase in concentration of Berberine. This was quantified by calculating the plating efficiency and survival fraction. Plating efficiency of MDA MB 231 \& MCF-7 cells declined as drug concentration increased.

\section{Effect of Epirubicin on cell survival}

Treatment of the breast cancer cells showed a lowest survival of $2.58 \%$ for $40 \mathrm{Nm}$ of Epirubicin for MCF-7 cells and $13.3 \%$ for $300 \mathrm{Nm}$ of Epirubicin for MDA MB 231 cells. (Figure 4 \& 5). Thus the reproductive capability of MDA MB 231 \& MCF-7 cells decreased significantly with increase in concentration of Epirubicin. This was quantified by calculating the plating efficiency and survival fraction. Plating efficiency of MDA MB 231 \& MCF-7 cells declined as drug concentration increased.

\section{Effect of combination of Berberine and Epirubicin on cell survival}

Concurrent treatment of Berberine and Epirubicin on MDA MB 231 \& MCF-7 cells showed good inhibition of the reproductive potential. The least survival for MCF-7 cells was found at combination concentrations of Berberine $45 \mu \mathrm{m}$ and Epirubicin 20nm. Whereas, for MDA MB 231 the least survival fraction of $11.8 \%$ was found at a concentration of Berberine $20 \mu \mathrm{m}$ and Epirubicin $300 \mathrm{~nm}$. The clonogenic assay results summarized in Table 4C \& 5B confirms that combination of Berberine and Epirubicin is more effective in killing breast cancer cells. Another noted inference from this result is that the concentration of Epirubicin required to effective cell kill is also reduced, thereby the side effects of Epirubicin therapy may also reduce considerably.

\section{Berberine reduced wound-healing migration of breast cancer cells}

The in-vitro wound healing assay or scratch assay is a simple and cost effective method to screen for compounds which can inhibit migration of cancer cells. This microscopic method essentially observes the closing of the wound or gap created on the cell monolayer and using microscope image analysis software the width or the gap can be measured, thereby giving a quantitative impact for the process of migration. This assay essentially measures the anti metastatic potential of Berberine alone and in combination with Epirubicin on MDA MB 231 and MCF-7 cells.
To investigate the anti metastatic properties of Berberine, wound healing assay was performed. The serial images of the wound at different time points showed that Berberine inhibited the migration of cells (Figure 6A). MDA MB 231 cells on treatment with $20 \mu \mathrm{m}$ of Berberine showed only $25.7 \%$ migration, as compared to the untreated vehicle control, which showed $70.4 \%$ migration at the end of $12 \mathrm{~h}$. This effect was better than Epirubicin (26.2\%). Further we also studied the combined effect of Berberine $(20 \mu \mathrm{m}$ and Epirubicin $300 \mathrm{Nm}$ ), which showed more potent inhibition of migration, $13.7 \%$. On closer examination of the gap or the wound on the MDA MB 231 cell monolayer treated with Berberine alone and in combination with Epirubicin, revealed that cells formed micro spike like structures on the surface and on the cell surface indicating formation of stress fibres and essentially signifying actin cytoskeleton remodelling. Whereas in the vehicle treated cell monolayer, these changes were not visible. The quantitative results of the wound healing assay on MDA MB 231 cells are summarized in Table 3A.

To confirm this inhibition of cell migration effect, we also performed the wound healing assay on MCF-7 cells and obtained serial images (Figure 6B) as well as quantified the migration areas. In MCF-7 cells on treatment with $90 \mu \mathrm{m}$ of Berberine showed only $23.4 \%$ migration at the end of $6 \mathrm{~h}$ treatment. While Epirubicin treated cell monolayer showed a migration rate of $29.6 \%$ at a concentration of $40 \mathrm{nM}$. On closer examination of the gap or the wound on the MCF-7 cell monolayer treated with Berberine alone and in combination with Epirubicin, revealed that cells formed micro spike like structures on the surface and on the cell surface indicating formation of stress fibres and in effect demonstrating actin cytoskeleton changes. Whereas in the vehicle treated cell monolayer, these changes were not perceptible and the cell motility was evident.

The inhibitory effect on cell migration was more potent on combination treatment. Berberine $90 \mu \mathrm{m} \&$ Epirubicin $40 \mathrm{Nm}$ combination treated MCF-7 cells showed only $6.5 \%$ migration at the end of $6 \mathrm{~h}$ as compared to the vehicle control, which showed $26.47 \%$. Breast cancer cells after treatment with the drugs essentially showed cytoskeleton remodelling and altered plasma membrane contours and combination treatments of Berberine and Epirubicin was very effective in inhibiting cell migration, important in the process of cancer metastasis. Thus Berberine and Epirubicin combinations can possibly inhibit breast cancer metastasis. The 
quantitative results of the wound healing assay on MCF7 cells are summarized in Table 3B.

Overall, wound healing assay performed on MCF-7 and MDA MB 231 cells have shown that Berberine \& Epirubicin combination has good effects on inhibiting cell migration.

Co-treatment of Berberine and Epirubicin exerts synergistic cytotoxicity against MDA MB 231 triple negative breast cancer cells

To determine the potential chemo preventive activity of Berberine and Epirubicin in combinations, we performed 3 different combination therapy experiments.

In the first set of assay, Co- treated MDA MB 231 cells with constant concentrations of Berberine $(31.5 \mu \mathrm{m})$ and increasing concentrations of Epirubicin (175 to $875 \mathrm{Nm}$ ) for $48 \mathrm{~h}$. At the end of the specified time point MTT assay was performed as mentioned earlier. The results showed Synergistic effect with a CI of 0.47 for a combination of Berberine $31.5 \mu \mathrm{m}$ and Epirubicin 875 Nm. Further the data showed with increasing concentrations of Epirubicin, the declined from 0.95 for Berberine $31.5 \mu \mathrm{m}$ and Epirubicin $175 \mathrm{Nm}$ to the best result of 0.47 for Berberine $31.5 \mu \mathrm{m}$ and Epirubicin 875 $\mathrm{Nm}$ in a dose dependent manner. In the entire range of concentrations tested, data calculated as combination index (CI) showed only Synergism, which is a novel finding for the study. The results of the assay are summarized in Table 4A.

In the next set of combination therapy assay, we pretreated MDA MB 231 cells with Berberine at a constant concentration of $31.5 \mu \mathrm{m}$ for $12 \mathrm{~h}$ and then treated with 2 different concentrations of Epirubicin $175 \mathrm{Nm} \& 875 \mathrm{Nm}$ for $48 \mathrm{~h}$. The results showed Synergism at the concentrations tested. The CI of 0.27 was obtained for a combination of Berberine $31.5 \mu \mathrm{m}$ and Epirubicin 875 $\mathrm{Nm}$. This pre-treatment of Berberine assay essentially exemplifies the fact that Berberine sensitizes the cells to Epirubicin and the CI value of 0.27 obtained on pre treatment is lower than the co treatment value of 0.47 . The results of the assay are summarized in Table 4B.

In another combination therapy experiment module, we pre-treated MDA MB 231 cells with 3 different concentrations of Epirubicin 175Nm, 350Nm \& $875 \mathrm{Nm}$ for $12 \mathrm{~h}$ and then treated with Berberine at a constant concentration of $31.5 \mu \mathrm{m}$ for $48 \mathrm{~h}$. The results showed Synergism at the concentrations tested. The CI of 0.38 was obtained for a combination of Epirubicin $175 \mathrm{Nm} \&$ Berberine $31.5 \mu \mathrm{m}$. The results of the assay are summarized in Table 4C.

It is important to note that in all the above combination therapy experiments the $\mathrm{CI}$ value were less than one, suggesting that the growth inhibitory effect of these compounds namely Epirubicin \& Berberine in combination was synergistic rather than additive or antagonistic.

\section{Co-treatment of Berberine and Epirubicin exerts synergistic cytotoxicity against MCF-7 breast cancer cells}

To establish whether the anti-tumor action of Berberine and Epirubicin in MCF-7 human breast cancer cells were synergistic, additive or antagonistic, the growth inhibitory effects were analysed after MTT assay. Results indicate that at a constant concentration of Berberine $(235 \mu \mathrm{m})$ and increasing concentrations of Epirubicin (43 to $106 \mathrm{Nm}$ ) for $48 \mathrm{~h}$. The results showed Synergistic effect with a best CI of 0.13 for a combination of Berberine $235 \mu \mathrm{m}$ and Epirubicin 106 $\mathrm{Nm}$. The results of the assay are summarized in Table $5 \mathrm{~A}$.

In the next set of combination therapy experiment, we pre-treated MCF-7 cells with 2 different concentrations of Epirubicin $21 \mathrm{Nm}, 43 \mathrm{Nm}$ for $12 \mathrm{~h}$ and then treated with Berberine at a constant concentration of $47 \mu \mathrm{m}$ for $48 \mathrm{~h}$. The results showed Synergism at the concentrations tested. The CI of 0.74 was obtained for a combination of Epirubicin $43 \mathrm{Nm} \&$ Berberine $47 \mu \mathrm{m}$. The results of the assay are summarized in Table 5B.

In summary, the combination therapy experiments carried out on two different breast cancer cell lines, namely MDA MB 231 and MCF-7 conclusively suggested a Synergistic effect of Berberine and Epirubicin. This data has laid the basis for pre clinical evaluation of Berberine and Epirubicin combination in breast cancer tumour models and probably propose the same combination in future human clinical trials subsequently.

\section{Quantitative PCR Analysis for important apoptotic markers}

Breast carcinogenesis is a multi step process involving several molecular players and in particular growth factor receptor signalling regulating cell death pathways are 
prominently implicated. In this regard, to examine the status of the intracellular signalling molecules responsible for the apoptotic activity in MDA MB 231 \& MCF-7 cells, mRNA expression levels of apoptotic markers (BAX, BCL-2, Caspase-3 and Caspase-9) were studied by real-time RT PCR following exposure to Berberine for $24 \mathrm{~h}$. Caspase $3 \& 9$ are proteases playing a crucial role in triggering apoptosis and quantifying the gene expression after drug treatment throws light on the cellular death machinery. Similarly, BCl-2 \& BAX important players in apoptotic signalling were also measured. (Figure 7\& 8).

To quantify the levels of selective genes involved in induction of apoptosis, MDA MB231 cells were treated with Berberine $(52.3 \mu \mathrm{m}), 826.7 \mathrm{Nm}$ Epirubicin, alone and in combination. MDA MB 231 cells treated with Vehicle control were used as controls for comparison. Results showed that the mRNA levels of the tested panel of apoptotic markers namely BAX, BCL-2, Caspase-3 and Caspase-9 were significantly altered in MDA MB 231 \& MCF-7 cells upon treatment with Berberine \& Epirubicin alone and in combination. The effect showed changes in levels of expression in treated cells, indicating a trigger of apoptosis.

To quantify the levels of selective genes involved in induction of apoptosis on MCF-7 cells were treated with Berberine $(200 \mu \mathrm{m}), 113 \mathrm{Nm}$ Epirubicin, alone and in combination. MCF-7 cells treated with Vehicle control were used as controls for comparison. The results showed significant changes in levels of expression of $\mathrm{Bcl}-2$, indicating a trigger of apoptosis cascade.

\section{Immunoblot analysis for selected apoptosis markers}

Further to gain a deeper insight into the mechanistic pathway of apoptosis induced by Berberine alone and in combination with Epirubicin, we next tested the protein levels of BAX, BCL-2, BID, Caspase-3 \& Caspase-9 after treatment. MDA MB 231 and MCF-7 cells after treatment with Berberine (IC50) and Epirubicin alone and in combinations, were lysed, proteins quantified and separated in SDS PAGE. They were immunoblotted using corresponding Abs and visualized.

MDA MB 231 \& MCF-7 cells treated with Berberine alone and in combination with Epirubicin showed caspase 9 activation, the apical caspase involved in the intrinsic pathway of apoptosis. As shown in (Figure 9), when MDA MB 231 cells were treated with Berberine alone and in combination with Epirubicin, procaspase-9 with a molecular weight of $50 \mathrm{kDa}$ was converted to an active form of caspase-9 with a molecular weight of 37 $\mathrm{kDa}$, indicative of apoptosis activation.

Together, these results strongly delineate that Berberine alone and in combination with Epirubicin induced apoptosis is mediated through the intrinsic/mitochondrial-mediated pathway by activation of Caspases.

Further we also showed deregulated expression of PI3 Kinase and mTOR. PI3-Kinase and mTOR are important intra cellular signalling nodes in growth factor receptor signalling, which are active in breast cancer cells. The difference in levels of these 2 proteins in breast cancer cells MDA MB 231 \& MCF-7, as shown by immune blot analysis provides evidence for alteration in growth factor receptor signalling upon treatment with Berberine and Epirubicin. Actin was used as the loading control to show uniform protein loading in the immunoblot. The results of the Immunoblot analysis are shown in Figure 9. Results show altered protein levels of the apoptotic proteins BAX, BCL-2, BID, Caspase-3 \& Caspase-9, indicating apoptosis is being triggered.

Table.1 Primer Sequences

\begin{tabular}{|c|c|c|c|}
\hline $\begin{array}{l}\text { S. } \\
\text { No }\end{array}$ & Name & Forward Primer & Reverse Primer \\
\hline 1. & BAX & 5'-TGCTTCAGGGTTTCATCCAG-3' & 5'-GGCGGCAATCATCCTCTG-3' \\
\hline 2. & BCL2 & $\begin{array}{l}\text { 5'-AGGAAGTGAACATTTCGGTGAC- } \\
3 \text {, }\end{array}$ & 5' GCTCAGTTCCAGGACCAGGC 3' \\
\hline 3. & $\begin{array}{l}\text { Caspase } \\
3\end{array}$ & 5'-ACATGGCGTGTCATAAAATACC-3' & 5'-CACAAAGCGACTGGATGAAC-3' \\
\hline 4. & $\begin{array}{l}\text { Caspase } \\
9\end{array}$ & $\begin{array}{l}\text { 5'-CCAGAGATTCGCAAACCAGAGG- } \\
3 \text {, }\end{array}$ & $\begin{array}{l}\text { 5'-GAGCACCGACATCACCAAATCC- } \\
\text { 3'. }\end{array}$ \\
\hline
\end{tabular}


Table.2 IC50 Values for Berberine \& Epirubicin on MCF-7 \& MDA MB 231 cells computed using GraphPad software

\begin{tabular}{|l|l|l|l|l|l|}
\hline Drugs & Time & MDA MB 231 & $\mathrm{R}^{2}$ & MCF-7 & $\mathrm{R}^{2}$ \\
\hline \multirow{3}{*}{ BBR $(\mu \mathrm{M})$} & 24 & 52.33 & 0.8868 & 200 & 0.87 \\
\cline { 2 - 6 } & 48 & 21.54 & 0.9227 & 187.9 & 0.95 \\
\cline { 2 - 6 } & 72 & 10.42 & 0.8739 & 163.1 & 0.95 \\
\hline \multirow{3}{*}{ EPI $(\mathrm{nM})$} & 24 & 826.7 & 0.9117 & 1130 & 0.97 \\
\cline { 2 - 6 } & 48 & 676.6 & 0.8828 & 85.2 & 0.94 \\
\cline { 2 - 6 } & 72 & 47.53 & 0.8296 & 7.69 & 0.88 \\
\hline
\end{tabular}

Table.3A \& B. Berberine alone \& in Combination with Epirubicin inhibits cell migration in MDA MB 231 \& MCF-7 cells

\begin{tabular}{|c|c|c|}
\hline MDA MB 231 cells & $\begin{array}{c}\% \text { of Migration } \\
\text { at } 12 \mathrm{~h}\end{array}$ & $\begin{array}{c}\% \text { of Migration } \\
\text { at } 24 \mathrm{~h}\end{array}$ \\
\hline Vehicle Control & 70.4 & 100 \\
\hline Berberine $20 \mu \mathrm{M}$ & 25.7 & 66.78 \\
\hline Epirubicim 300nM & 26.24 & 44.56 \\
\hline Berberine $20 \mu \mathrm{M}+$ Epirubicin 300nM & 13.73 & 42.6 \\
\hline MCF-7 cells & $\begin{array}{c}\% \text { of Migration } \\
\text { at } 6 \mathrm{~h}\end{array}$ & $\begin{array}{c}\% \text { of Migration } \\
\text { at } 12 \mathrm{~h}\end{array}$ \\
\hline Vehicle Control & 26.47 & 59.23 \\
\hline Berberine $90 \mu \mathrm{M}$ & 23.42 & 38.67 \\
\hline Epirubicim 40nM & 29.66 & 52.36 \\
\hline Berberine $90 \mu \mathrm{M}+$ Epirubicim $40 \mathrm{nM}$ & 6.51 & 22.9 \\
\hline
\end{tabular}

Table.5A\& B In-Vitro Combination Therapy on MCF-7 cells -with Berberine \& Epirubicin. A. Simultaneous treatment of Epirubicin \& Berberine (48h). B. Pre treatment with Epirubicin (12h) followed by treatment with Berberine (48h)

\begin{tabular}{|l|l|l|l|l|}
\hline \multicolumn{5}{|c|}{ In Vitro Combination Therapy } \\
\hline Epirubicin $[\mathrm{nM}]$ & Berberine $[\mu \mathrm{M}]$ & $\begin{array}{c}\text { Fraction } \\
\text { affected }\left[\mathrm{F}_{\mathrm{a}}\right]\end{array}$ & $\mathrm{Cl}$ & $\mathrm{Cl}$ effect \\
\hline 43 & 235 & 0.67 & 0.76 & Synergism \\
\hline 85 & 235 & 0.76 & 0.32 & Synergism \\
\hline 106 & 235 & 0.84 & 0.13 & Synergism \\
\hline
\end{tabular}

\begin{tabular}{|l|l|l|l|c|}
\hline \multicolumn{5}{|c|}{ In Vitro Combination Therapy } \\
\hline \multicolumn{5}{|c|}{ Pre treatment with Epirubicin $\begin{array}{l}(12 \mathrm{~h}) \text { followed by treatment with Berberine }(48 \mathrm{~h}) \\
\text { on MCF-7 cell line }\end{array}$} \\
\hline Epirubicin $[\mathrm{nM}]$ & Berberine $[\mu \mathrm{M}]$ & $\begin{array}{c}\text { Fraction } \\
\text { affected }\left[\mathrm{F}_{\mathrm{a}}\right]\end{array}$ & $\mathrm{Cl}$ & $\mathrm{Cl}$ effect \\
\hline 21 & 47 & 0.6 & 0.83 & Synergism \\
\hline 43 & 47 & 0.74 & 0.74 & Synergism \\
\hline
\end{tabular}


Table.4 In-Vitro Combination Therapy on MDA MB 231 cells - with Berberine \& Epirubicin. A. Simultaneous treatment of Epirubicin \& Berberine (48h). B. Pre treatment of Berberine (12h) followed by treatment with Epirubicin (48h). C Pre treatment with Epirubicin (12h) followed by treatment with Berberine (48h)

\begin{tabular}{|c|c|c|c|c|}
\hline \multicolumn{5}{|c|}{ In Vitro Combination Therapy } \\
\hline \multicolumn{5}{|c|}{ Simultaneous treatment (48h) of Epirubicin and Berberine on MDA MB-231 cell line } \\
\hline Epirubicin [nM] & Berberine $[\mu \mathrm{M}]$ & $\begin{array}{c}\text { Fraction } \\
\text { affected }\left[F_{\mathrm{a}}\right]\end{array}$ & $\mathrm{Cl}$ & $\mathrm{Cl}$ effect \\
\hline 175 & 31.5 & 0.494 & 0.95772 & Synergism \\
\hline 350 & 31.5 & 0.55 & 0.88225 & Synergism \\
\hline 700 & 31.5 & 0.64 & 0.69833 & Synergism \\
\hline
\end{tabular}

\begin{tabular}{|l|l|l|l|c|}
\hline \multicolumn{5}{|c|}{ In Vitro Combination Therapy } \\
\cline { 2 - 6 } & \multicolumn{5}{|c|}{ Pre treatment with Berberine (12h) followed by treatment with Epirubicin $(48 \mathrm{~h})$} \\
on MDA MB-231 cell line & Cl & Clfect \\
\hline 175 & Berberine $[\mu \mathrm{M}]$ & $\begin{array}{c}\text { Fraction } \\
\text { affected }\left[\mathrm{F}_{\mathrm{a}}\right]\end{array}$ & \multicolumn{1}{c|}{$\mathrm{Cl}$} \\
\hline 875 & 31.5 & 0.5 & 0.72588 & Synergism \\
\hline
\end{tabular}

\begin{tabular}{|l|l|l|l|c|}
\hline \multicolumn{5}{|c|}{ In Vitro Combination Therapy } \\
\cline { 2 - 6 } & \multicolumn{5}{|c|}{ Pre treatment with Epirubicin (12h) followed by treatment with Berberine $(48 \mathrm{~h})$} \\
on MDA MB-231 cell line & Cl effect \\
\hline Epirubicin [nM] & Berberine $[\mu \mathrm{M}]$ & $\begin{array}{c}\text { Fraction } \\
\text { affected }\left[\mathrm{F}_{\mathrm{a}}\right]\end{array}$ & $\mathrm{Cl}$ & Synergism \\
\hline 175 & 31.5 & 0.64 & 0.38318 & Synergism \\
\hline 350 & 31.5 & 0.58 & 0.6609 & Synergism \\
\hline 875 & 31.5 & 0.68 & 0.6482 &
\end{tabular}


Figure.1 Growth inhibitory effects of Berberine (BBR) in MDA MB 231breast cancer cells when compared with vehicle control. Representative micrographs from random fields of view (magnification 20X) of indicated cells treated with and without Berberine

Vehicle Control

24h
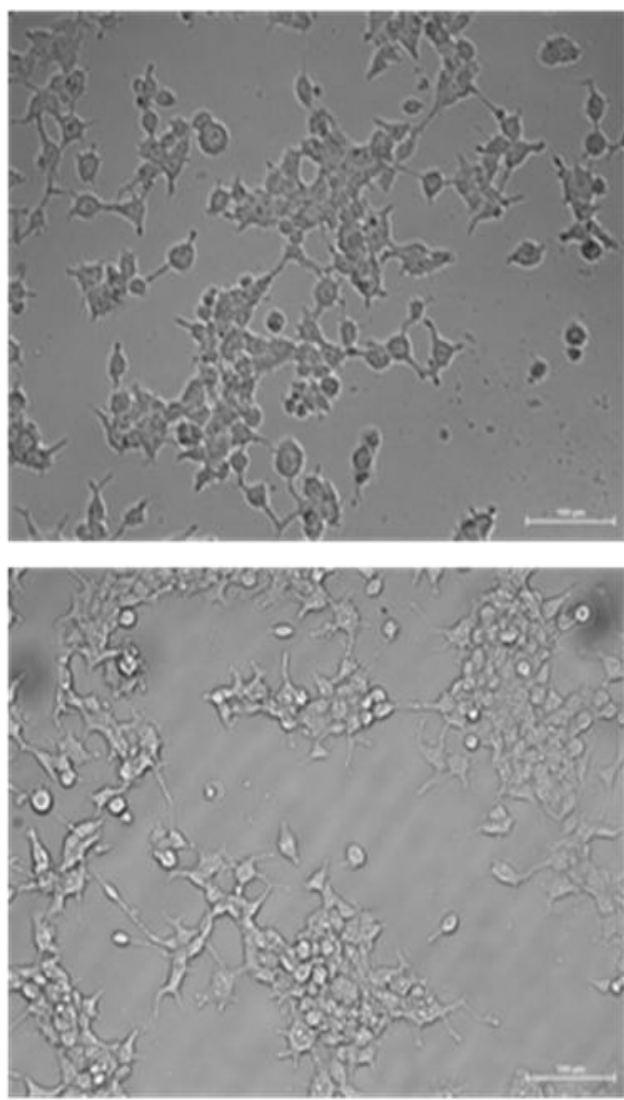

$48 h$

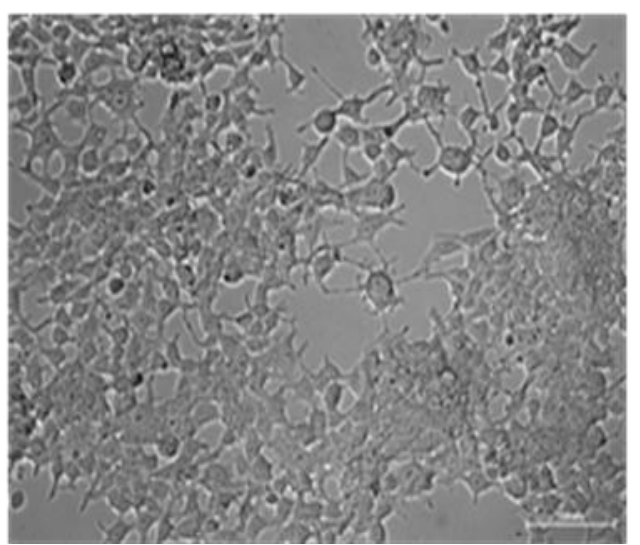

$72 \mathrm{~h}$
$120 \mu \mathrm{m}$ BBR

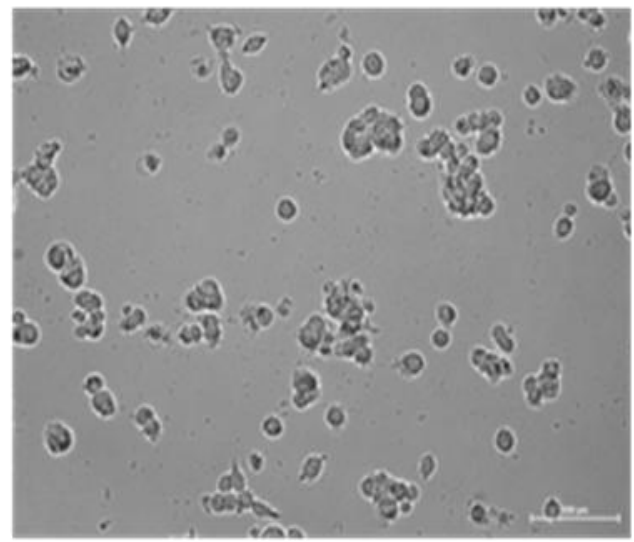

M

$\mathrm{D}$

A

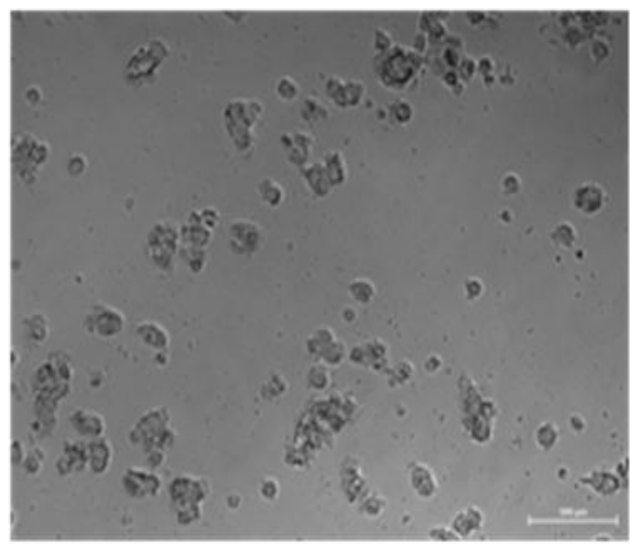

M

B

2

3

1

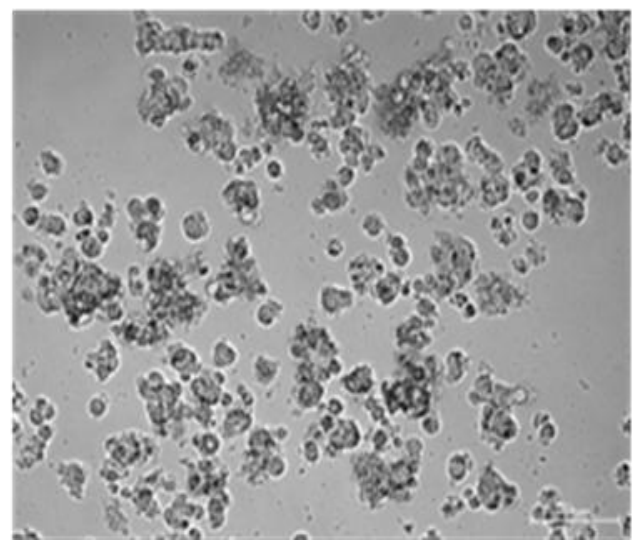


Figure.2 Growth inhibitory effects of Berberine (BBR) in MCF-7 breast cancer cells when compared with vehicle control. Representative micrographs from random fields of view (magnification 20X) of indicated cells treated with and without Berberine

Vehicle Control

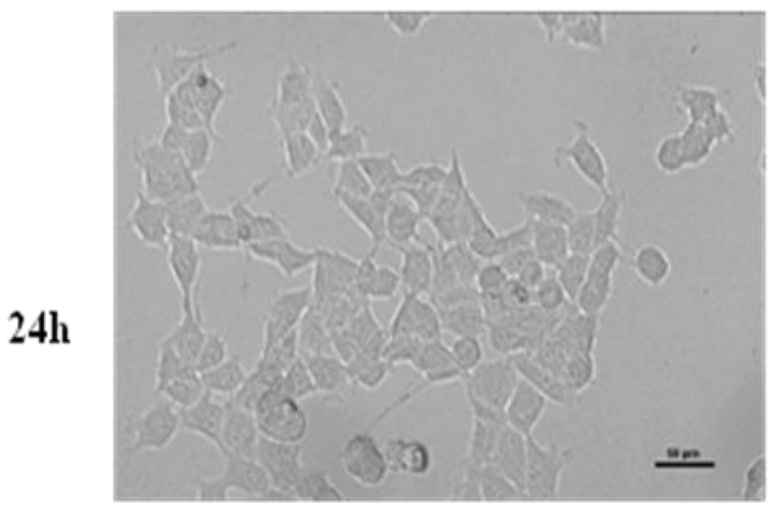

$48 \mathrm{~h}$
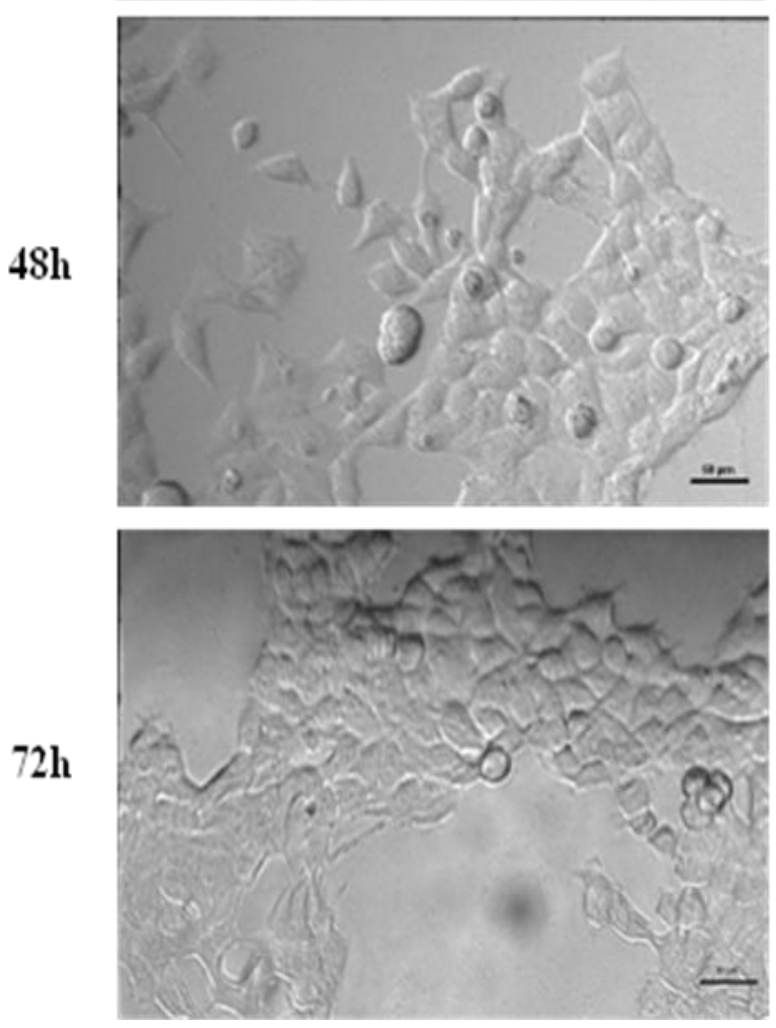

$300 \mu \mathrm{m}$ BBR

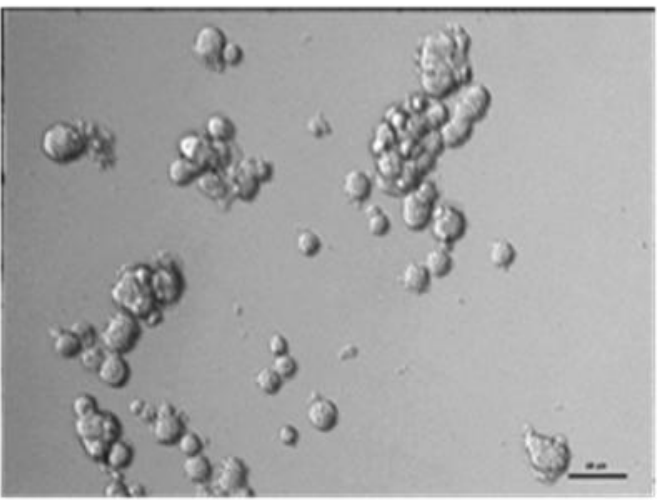

$\mathrm{M}$

$\mathrm{C}$

$\mathrm{F}$
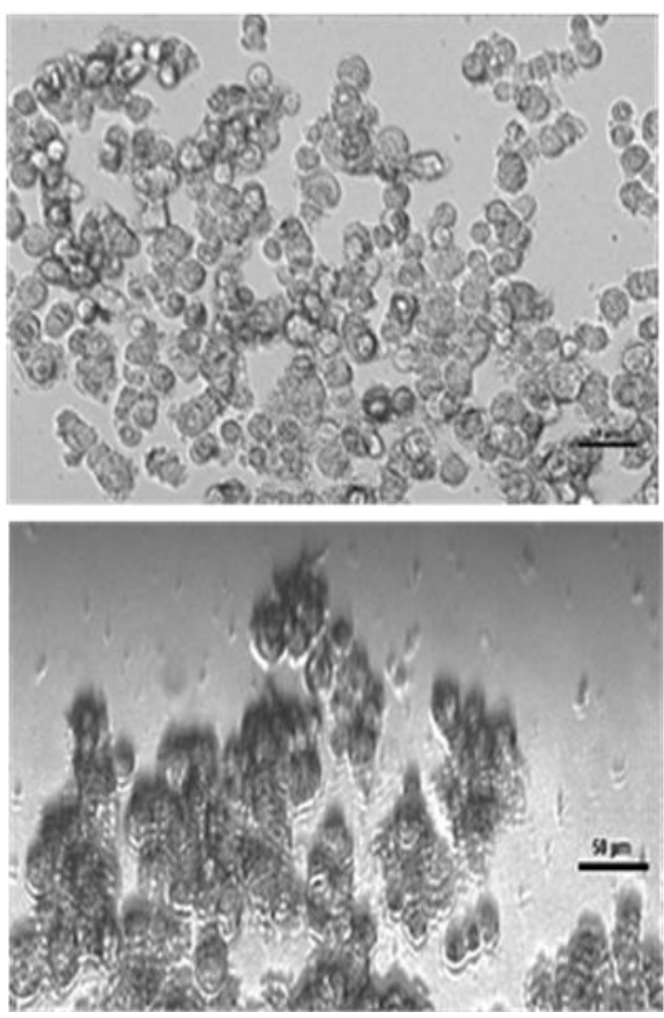
Figure.3 Anti-proliferative effects of Berberine on A. MDA MB 231 \& B. MCF-7 breast cancer cells. Berberine Preferentially Inhibits Breast Cancer Cell Proliferation

Berberine $24 \mathrm{hr}$

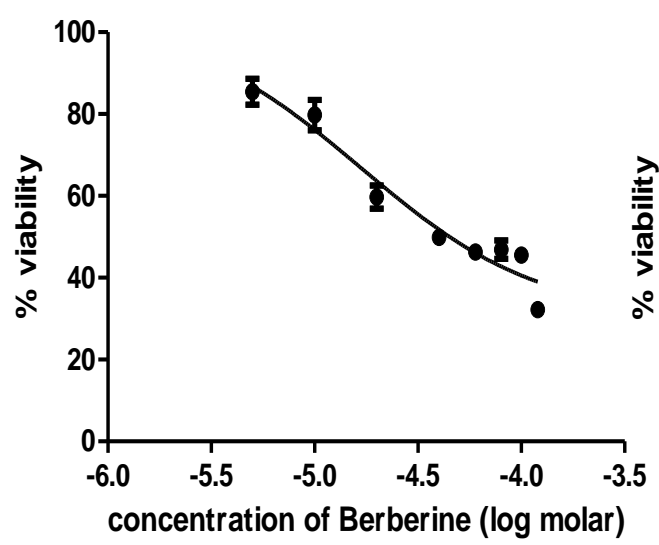

Berberine $48 \mathrm{hr}$

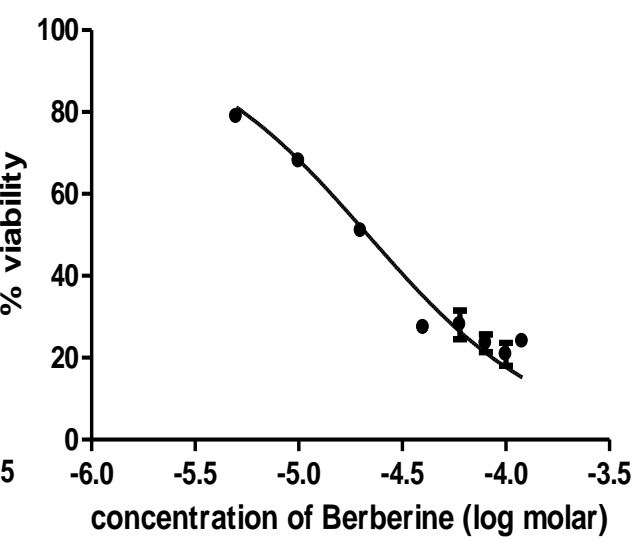

A. MDA MB 231
Berberine $72 \mathrm{hr}$

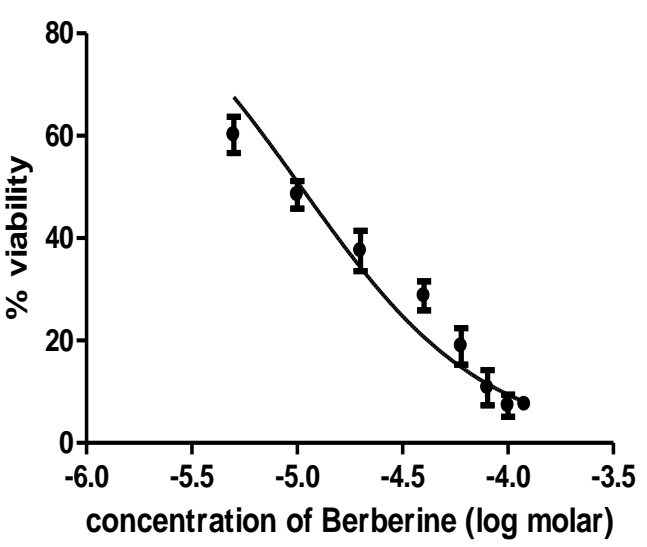

B. $\mathrm{MCF}-7$

MCF-7 treated with Berberine - $24 \mathrm{hr}$

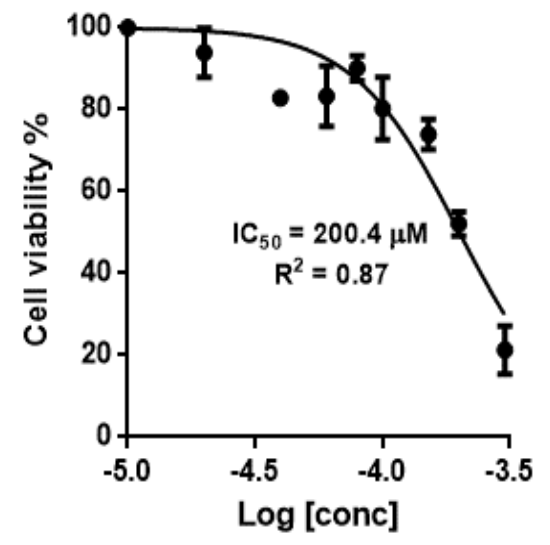

MCF-7 treated with Berberine - $48 \mathrm{hr}$

MCF-7 treated with Berberine $-72 \mathrm{hr}$
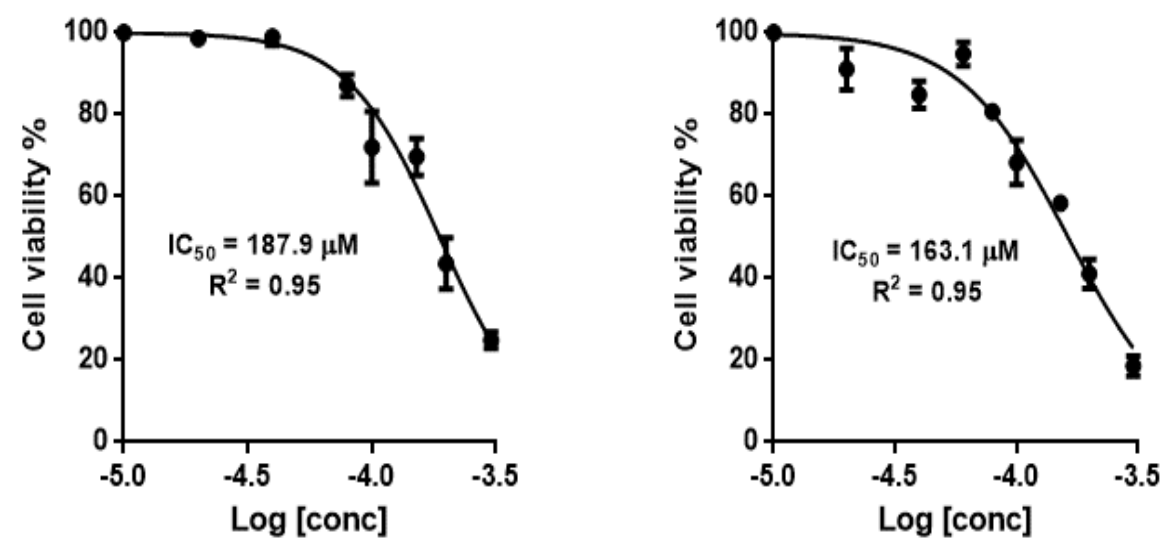

The anti-proliferative effects were determined by the MTT assay. These results are presented as percentage of live cells as against log scale of molar concentrations 
Figure.4 Clonogenic Assay on MCF-7 breast cancer cells after BBR \& EPI treatment alone \& in Combination. Berberine at different concentrations inhibits clonogenicity of MCF-7 cells as determined by clonogenic cell survival assay. A. Quantitative representation of reduction in number of colonies with representative images. B. Graphical representation for Inhibition of reproductive potential of MCF-7 cells after treatment as determined by Clonogenic assay. C. Tabulation of the \% Survival after treatment with Berberine \& Epirubicin alone and in combination. P.E:

Plating Efficiency; \% S: Percentage Survival

A.

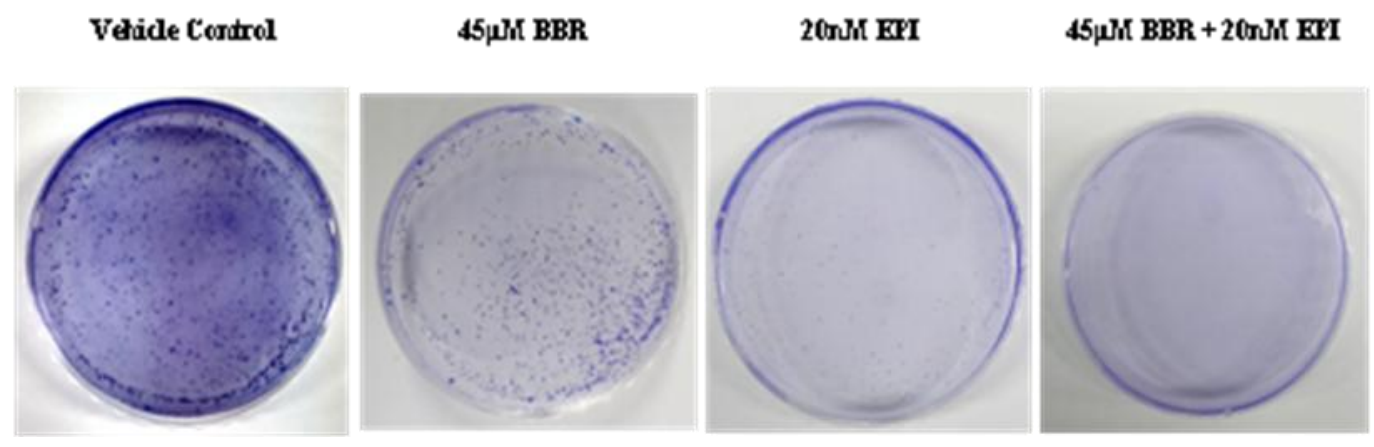

B Clonogenic Cell Survival Assay
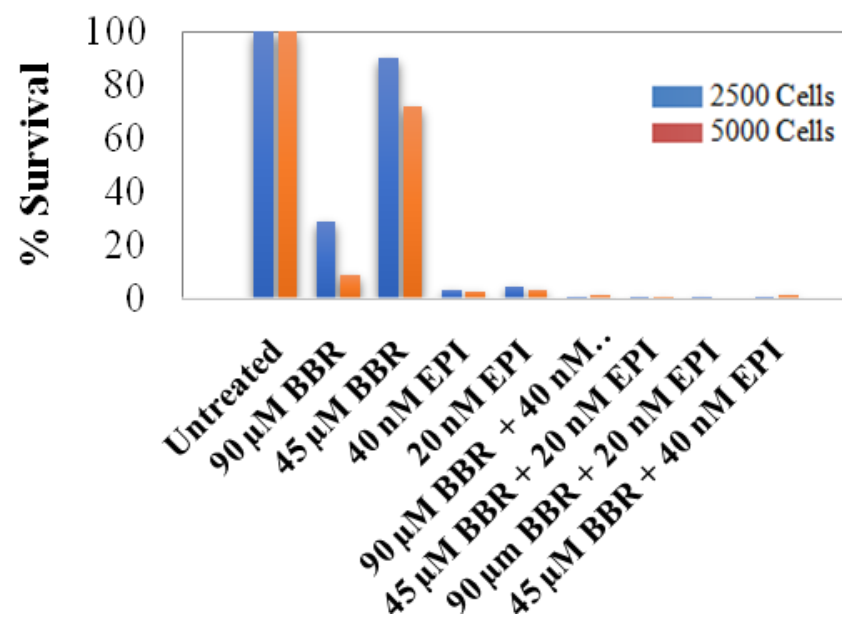

\begin{tabular}{|c|c|c|c|c|c|c|c|c|c|}
\hline & \begin{tabular}{|l|} 
Vehicle \\
Control
\end{tabular} & \multicolumn{2}{|c|}{ Berberine } & \multicolumn{2}{|c|}{ Epirubicin } & \multicolumn{4}{|c|}{ Combination } \\
\hline $\begin{array}{l}\text { Total No.of } \\
\text { Cells \& \%S }\end{array}$ & & $45 \mu \mathrm{M}$ & $90 \mu \mathrm{M}$ & $20 \mathrm{nM}$ & $40 \mathrm{nM}$ & $\begin{array}{c}\text { Berberine } \\
(90 \mu \mathrm{M})+ \\
\text { Epirubicin } \\
(40 \mathrm{nM})\end{array}$ & $\mid \begin{array}{c}\text { Berberine } \\
(45 \mu \mathrm{M})+ \\
\text { Epirubicin } \\
(20 \mathrm{nM})\end{array}$ & $\begin{array}{c}\text { Berberine } \\
(90 \mu \mathrm{M})+ \\
\text { Epirubicin } \\
(20 \mathrm{nM})\end{array}$ & $\begin{array}{c}\text { Berberine } \\
(45 \mu \mathrm{M})+ \\
\text { Epirubicin } \\
(40 \mathrm{nM})\end{array}$ \\
\hline $2500 \& \% \mathrm{~S}$ & 100 & 90 & 28.95 & 4.74 & 3.16 & 1.05 & 1.05 & 1.05 & 1.05 \\
\hline $5000 \& \% S$ & 100 & 72.15 & 8.86 & 3.38 & 2.58 & 1.29 & 0.64 & 0 & 1.29 \\
\hline
\end{tabular}


Figure.5 Clonogenic Assay on MDA MB 231 breast cancer cells after BBR \& EPI treatment alone \& in Combination. Berberine at different concentrations inhibits clonogenicity of MCF-7 cells as determined by clonogenic cell survival assay. A. Graphical representation for Inhibition of reproductive potential of MDA MB 231 cells after treatment as determined by Clonogenic assay. B. Tabulation of the \% Survival after treatment with Berberine \& Epirubicin alone and in combination. P.E: Plating Efficiency; \% S: Percentage Survival

A.

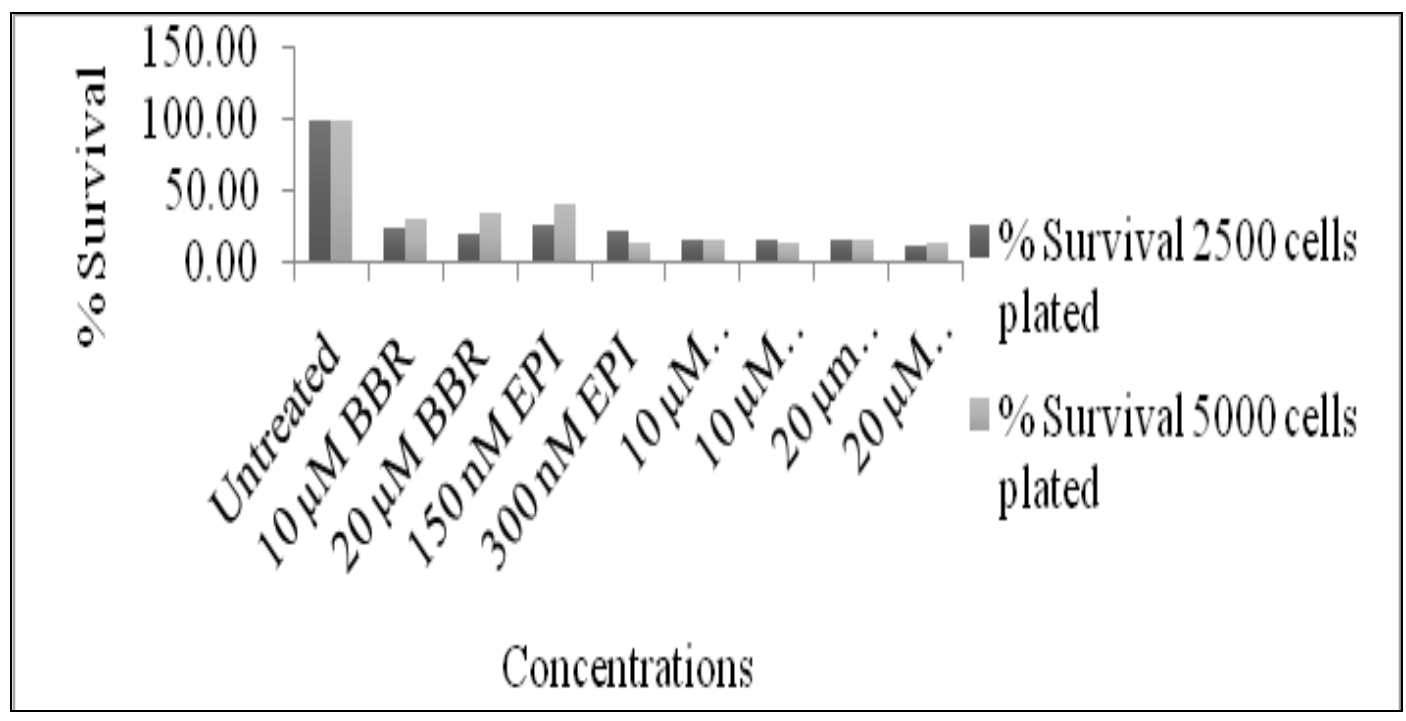

B.

\begin{tabular}{|c|c|c|c|c|c|c|c|c|c|}
\hline & $\begin{array}{l}\text { Vehicle } \\
\text { Control }\end{array}$ & \multicolumn{2}{|c|}{ Berberine } & \multicolumn{2}{|c|}{ Epirubicin } & \multicolumn{4}{|c|}{ Combination } \\
\hline $\begin{array}{l}\text { Total No. of } \\
\text { Cells \& \%S }\end{array}$ & & $10 \mu \mathrm{M}$ & $20 \mu \mathrm{M}$ & $150 \mathrm{nM}$ & $300 \mathrm{nM}$ & $\begin{array}{c}\text { Berberine } \\
(10 \mu \mathrm{M})+ \\
\text { Epirubicin } \\
(150 \mathrm{nM})\end{array}$ & $\begin{array}{c}\text { Berberine } \\
(10 \mu \mathrm{M})+ \\
\text { Epirubicin } \\
(300 \mathrm{nM})\end{array}$ & $\begin{array}{l}\text { Berberine } \\
(20 \mu \mathrm{M})+ \\
\text { Epirubicin } \\
(150 \mathrm{nM})\end{array}$ & $\begin{array}{l}\text { Berberine } \\
(20 \mu \mathrm{M})+ \\
\text { Epirubicin } \\
(300 \mathrm{nM})\end{array}$ \\
\hline $2500 \& \% \mathrm{~S}$ & 100 & 23.03 & 19.1 & 26.97 & 22.47 & 15.17 & 16.29 & 15.73 & 11.80 \\
\hline $5000 \& \% \mathrm{~S}$ & 100 & 29.74 & 34.36 & 40.51 & 13.33 & 15.38 & 12.31 & 15.90 & 13.33 \\
\hline
\end{tabular}


Figure.6 Berberine alone \& in Combination with Epirubicin inhibits cell migration in A. MDA MB 231 \& B. MCF-7 cells

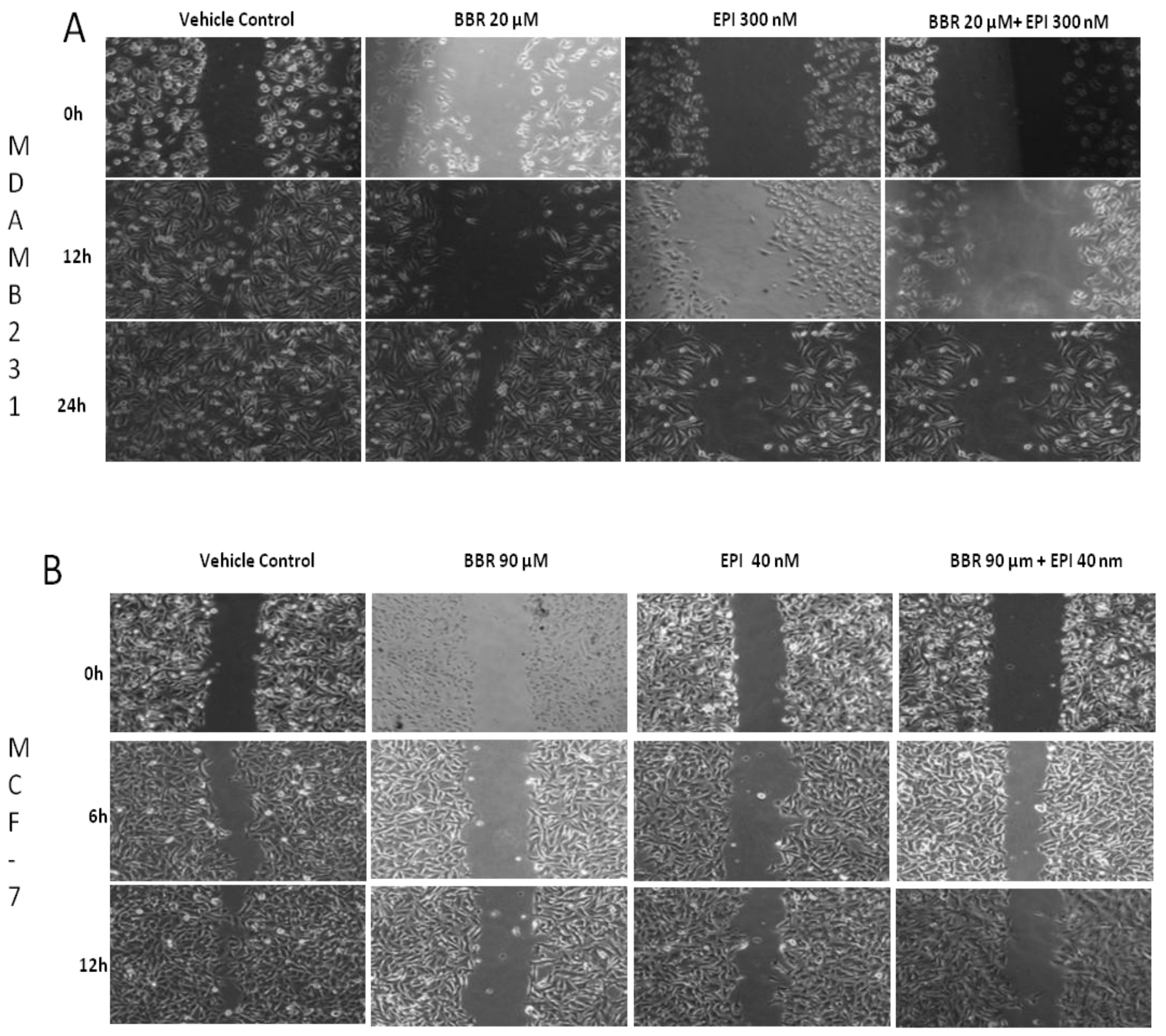


Figure.7 qPCR analysis of apoptotic markers in MDA MB 231 cells after treatment. qPCR analysis for (A) Bcl-2(B) BAX (C) Caspase 3 (D) Caspase 9. GAPDH was used as internal control for normalization

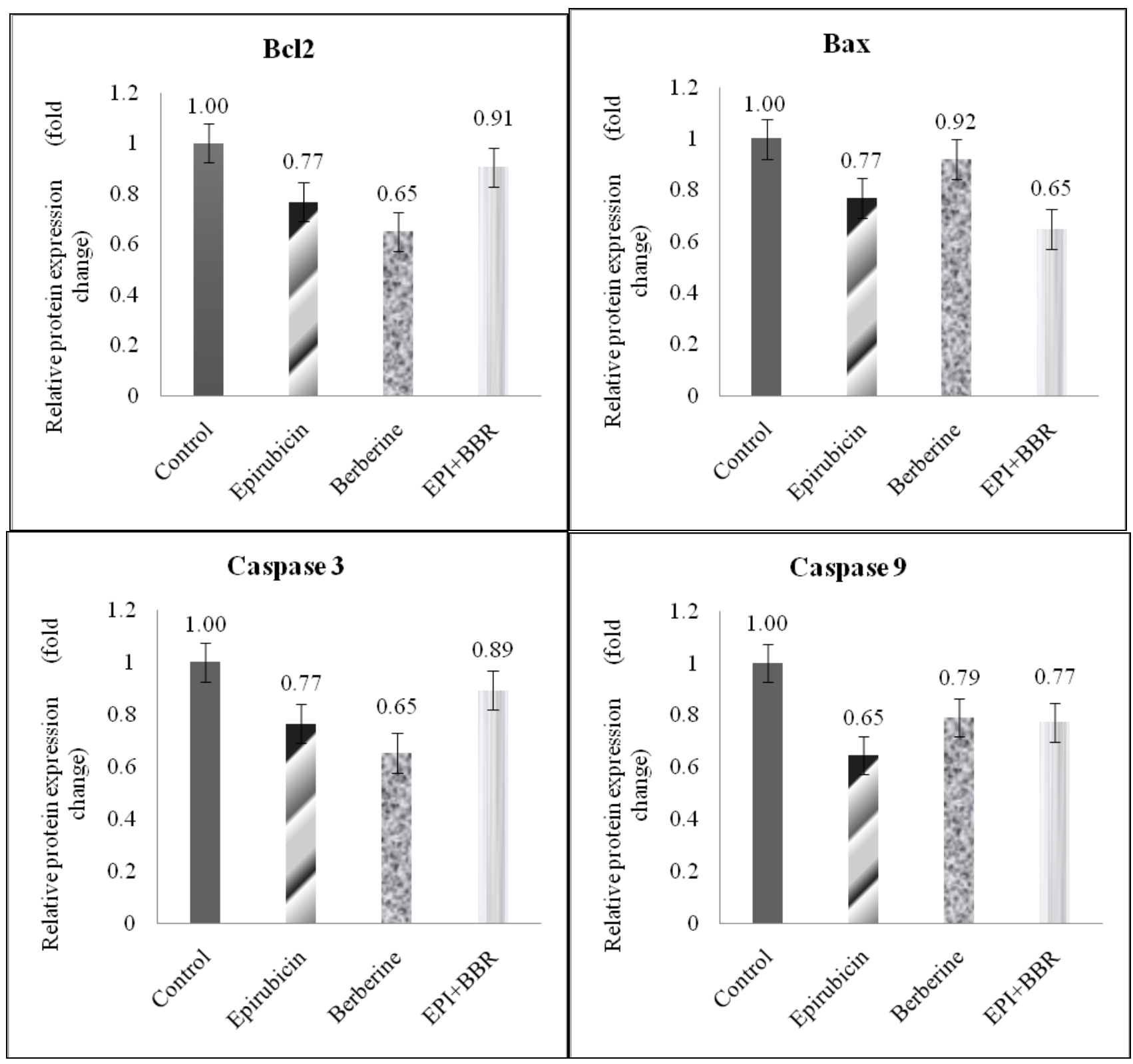


Figure.8 qPCR analysis of apoptotic markers in MCF-7 cells after treatment. qPCR analysis for (A) Bcl-2 GAPDH was used as internal control for normalization

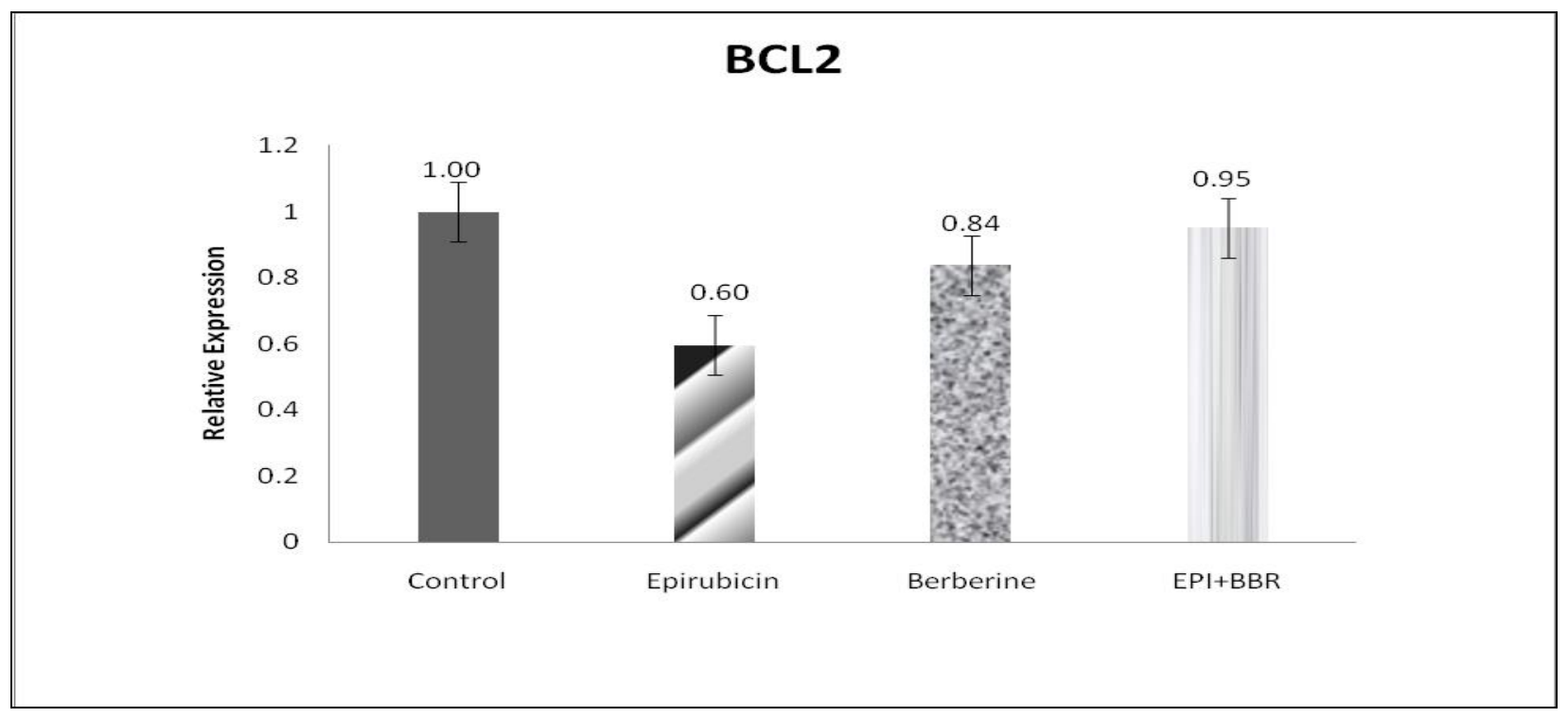

Figure.9 Western blot analysis of important marker proteins for Apoptosis in MDA-MB231 \& MCF-7 cells exposed to Berberine. Actin was used as loading control
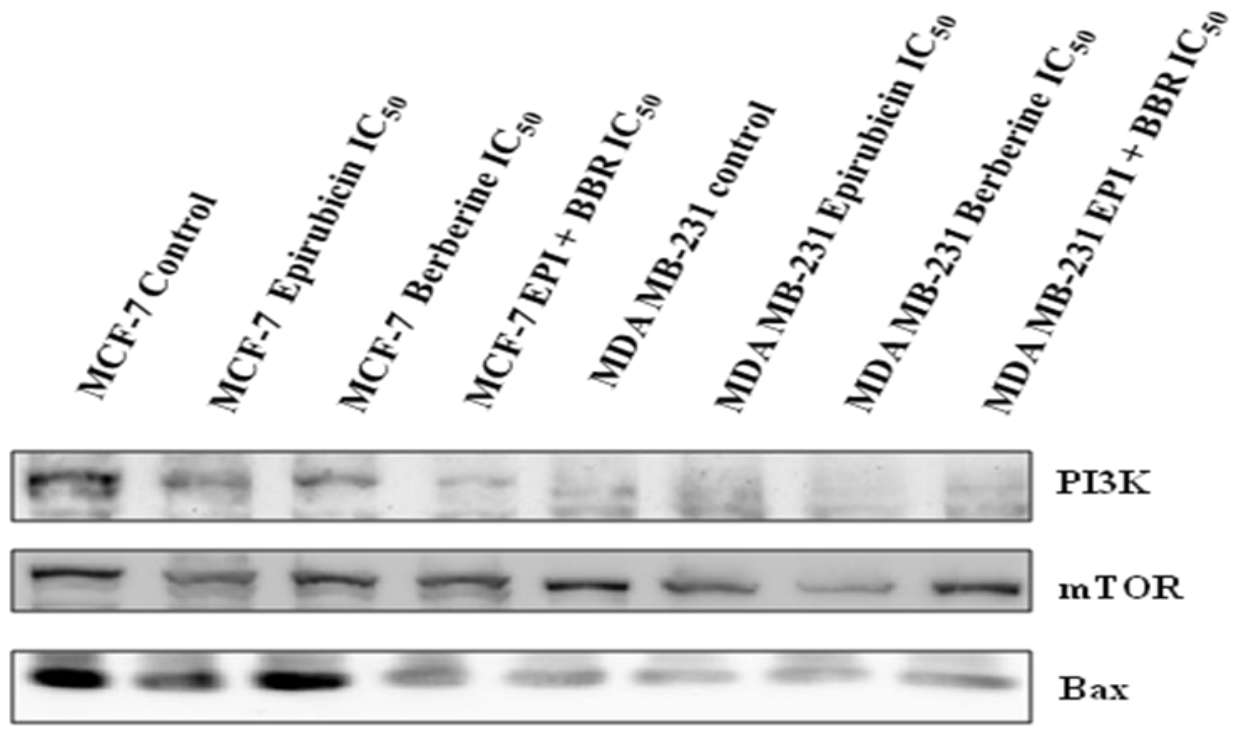

PI3K

mT OR

Bax

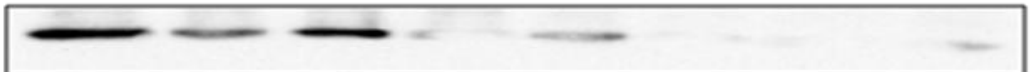

$\mathrm{Bcl} 2$

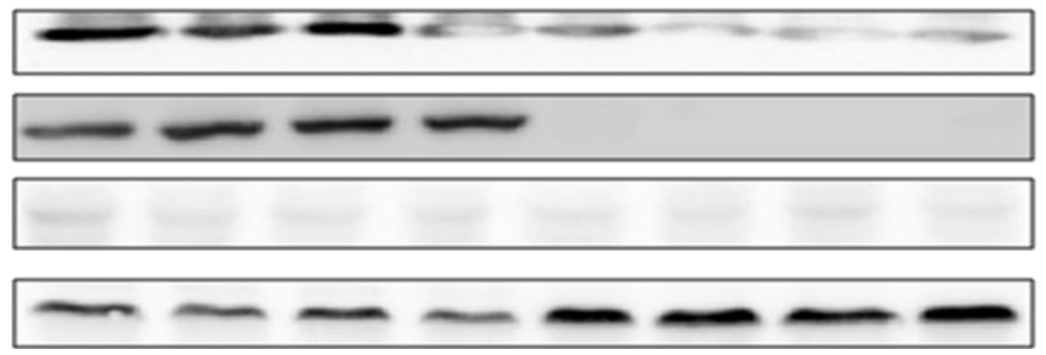

Bid

Caspase9

Casp ase 3

Actin 
Supplementary Figure.1 Growth inhibitory effects of Epirubicin (EPI) on breast cancer cells. Representative micrographs from random fields of view (magnification 20X) of indicated cells treated with and without Epirubicin

Control

$24 h$

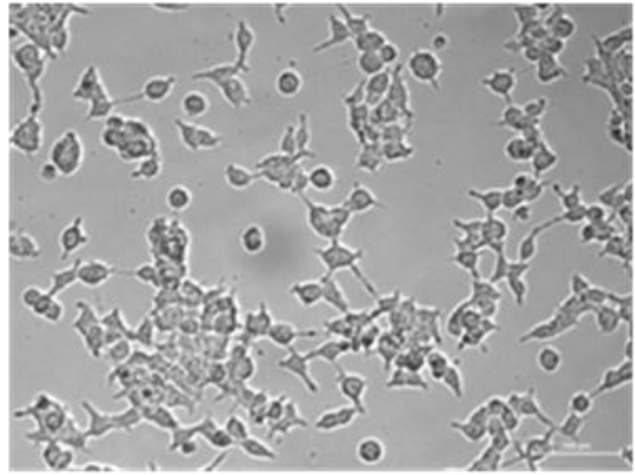

$48 h$
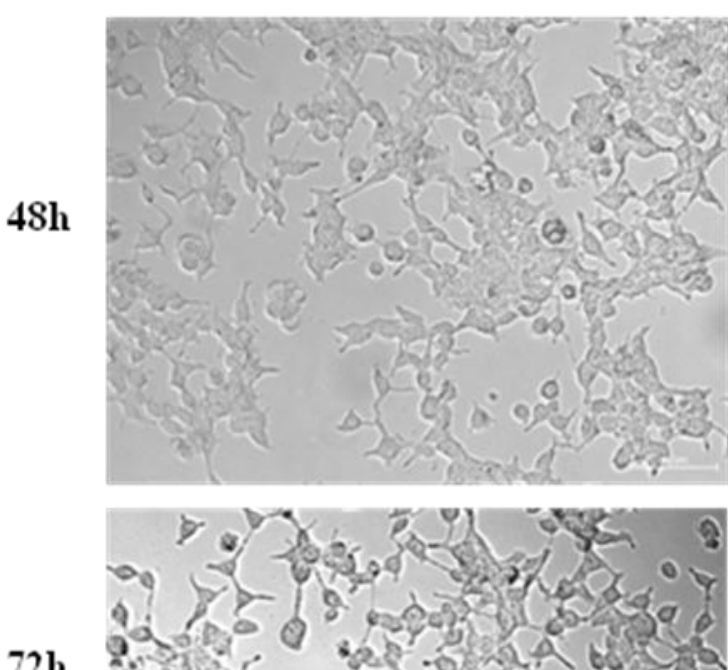

2000 nMEPI
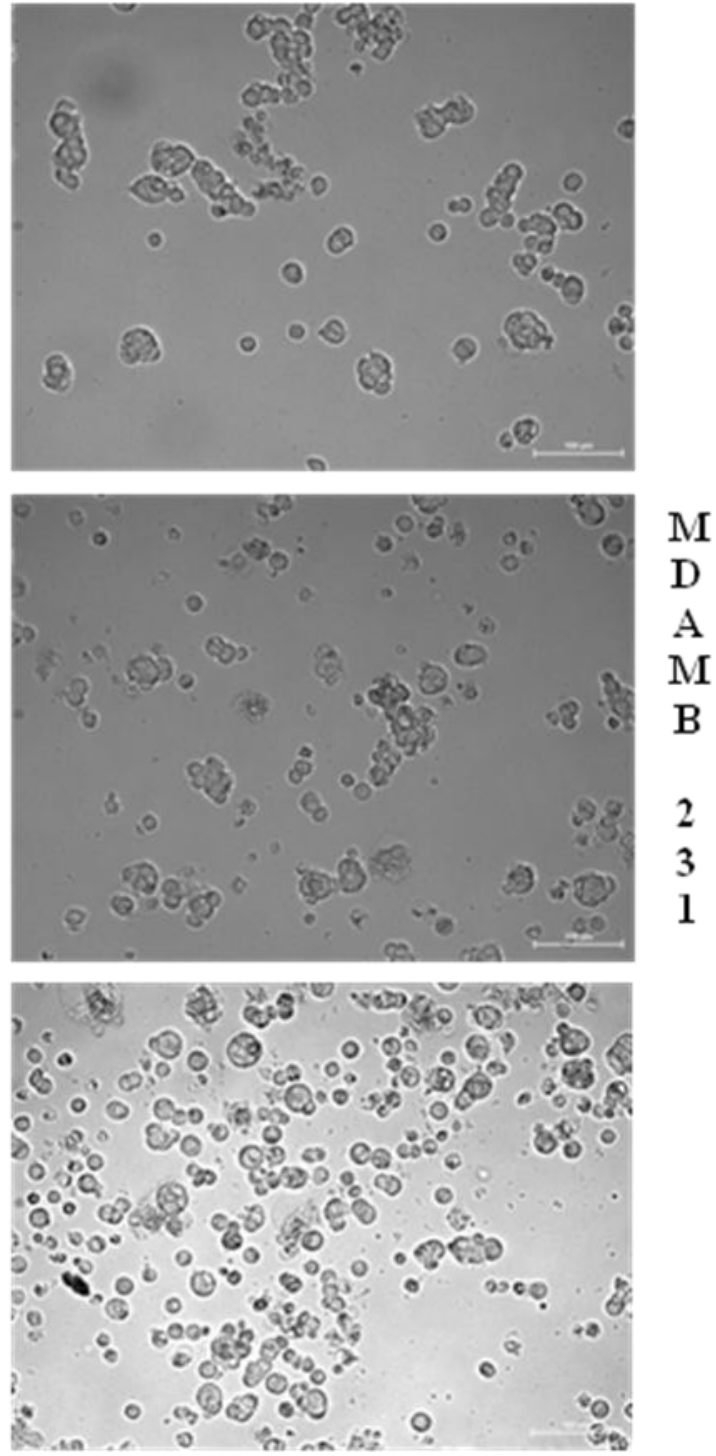
Supplementary Figure.2 Growth inhibitory effects of Epirubicin (EPI) on breast cancer cells. Representative micrographs from random fields of view (magnification 20X) of indicated cells treated with and without Epirubicin
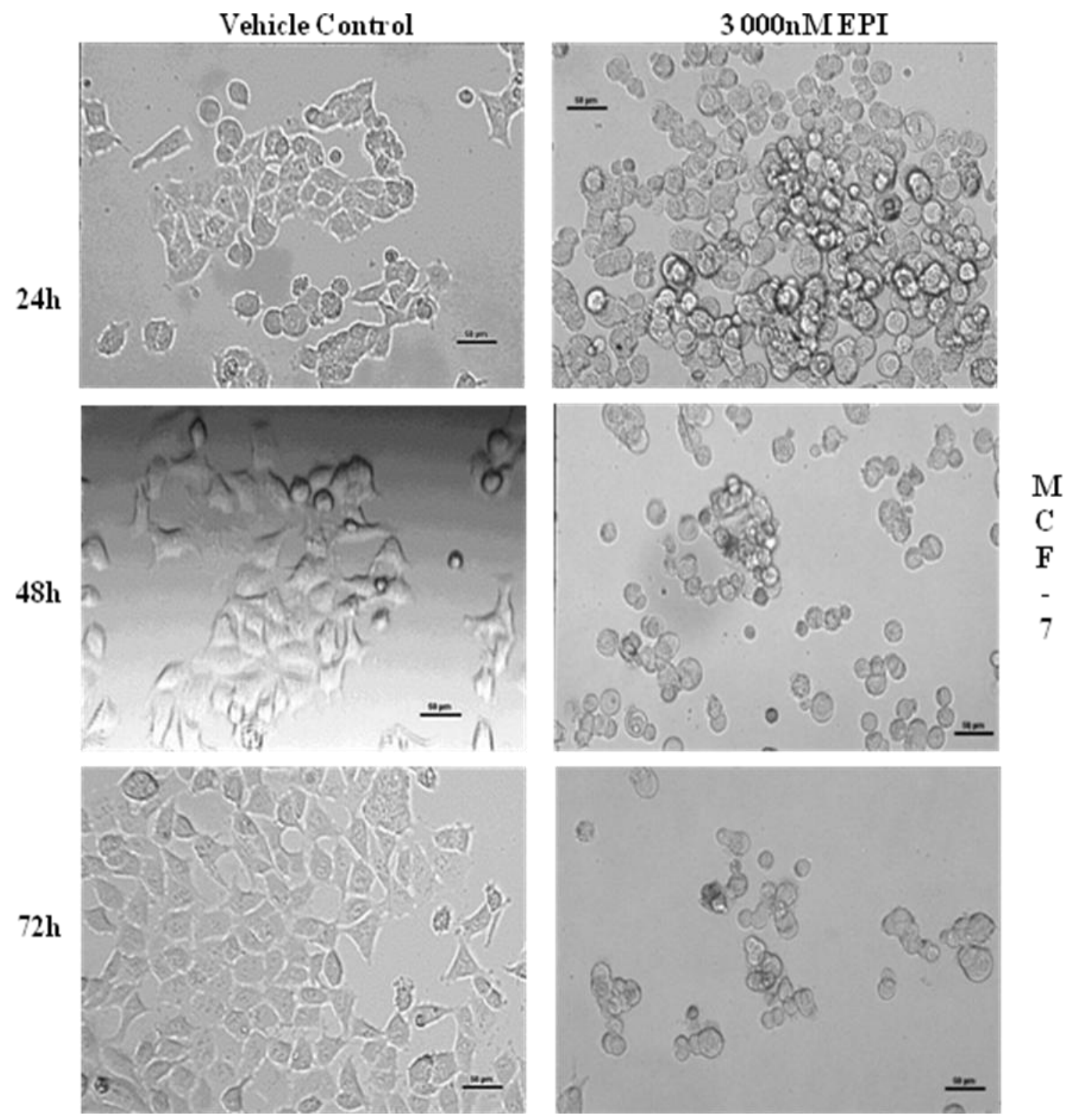
Supplementary Figure.3 Anti-proliferative effects of Epirubicin on MDA MB 231 breast cancer cells
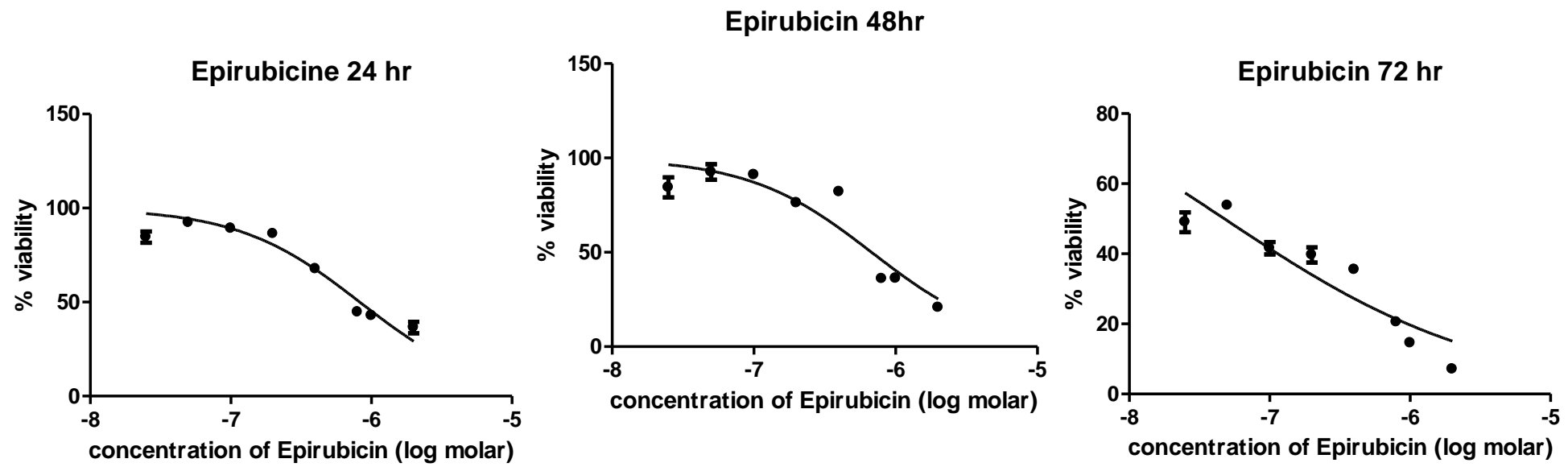

Supplementary Figure.4 Anti-proliferative effects of Epirubicin on MCF-7 breast cancer cells

MCF-7 treated with Epirubicin - $24 \mathrm{hr}$

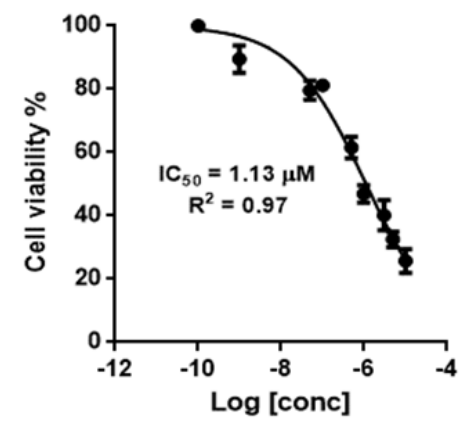

MCF-7 treated with Epirubicin - $48 \mathrm{hr}$

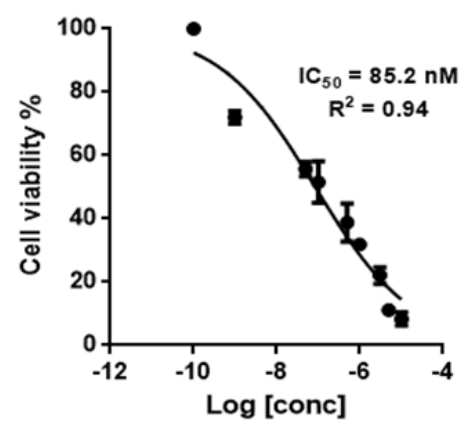

MCF-7 treated with Epirubicin - $72 \mathrm{hr}$

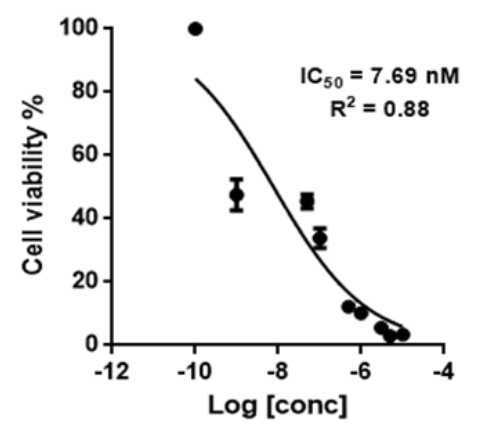

Mammary carcinoma is the foremost cause of cancer associated deaths among women world over (Surh (2003)). Great advances have been consummated in comprehending breast carcinogenesis and its progression. On the other hand development of treatment for this cancer has been relatively slow and also affluent (Nobili et al., (2009)) The objective to be achieved in breast cancer chemotherapy is to discern chemotherapeutic agents with extreme specificity, bioavailability and nominal toxicity to normal tissues and organs. Several groups throughout the world have ventured on identifying lead drug molecules from natural resources that fulfill these needs (Saldanha et al., (2012)). Thus photochemistry research has remained in the forefront of basic biomedical research in the recent years ${ }^{15}$. Thus the present work essentially attempts to contribute meaningful outcomes in this arena.
Berberine is a natural dietary product which has shown promising cancer chemotherapeutic potential. It is an isoquinoline quaternary alkaloid present in rhizome of numerous medicinal plants. Several mechanisms by which Berberine inhibits the proliferation of different cancer cell lines have been reported. Among them, the killing of cancer cells by the activation of apoptosis is the best characterized. In the present study Berberine alone and in combination with a widely used anti-cancer agent Epirubicin were analyzed for their effect on cell viability, induction of apoptosis, clonogenicity and cell migration. Further to these cell biology assays, combination chemotherapy experiments using Berberine and Epirubicin were also carried out in three different settings to churn out a translational relevance for the study. The study envisaged to propose that Berberine can be used in combination with Epirubicin for treatment of 
breast cancers. Experimental studies using Berberine alone and in combination with Epirubicin have evidently shown the inhibition of cell growth on cultured breast cancer cells and the combination effects are synergistic, which is a novel finding.

\section{Conclusion}

This novel study showcased the synergistic effect of Berberine and Epirubicin in breast cancer cell lines MCF-7 and MDA MB-231. Berberine is known to induce apoptosis in cancer cells and the combination of the two drugs shows inhibition on cell growth and higher expression of apoptotic markers in-vitro. This preliminary study suggests that the combination of Berberine and Epirubicin can kill the cancer cells without harming the normal cells and further studies are required before bringing this combination into clinical practice.

\section{References}

1. Torres MP, Rachagani S, Purohit V, Pandey P, Joshi S, Moore ED, Johansson SL, Singh PK, Ganti AK, Batra SK. Graviola: A novel promising natural-derived drug that inhibits tumorigenicity and metastasis of pancreatic cancer cells in vitro and in vivo through altering cell metabolism. Cancer letters; 2012 Oct 1; 323(1): 29-40.

2. Malvia S, Bagadi SA, Dubey US, Saxena S. Epidemiology of breast cancer in Indian women. Asia Pac J Clin Oncol; 2017 Aug; 13(4): 289295.

3. Allemani C, Matsuda T, Di Carlo V, Harewood R, Matz M, Nikšić M, Bonaventure A, Valkov M, Johnson CJ, Estève J, Ogunbiyi OJ. Global surveillance of trends in cancer survival 2000-14 (CONCORD-3): analysis of individual records for 37513025 patients diagnosed with one of 18 cancers from 322 population-based registries in 71 countries. The Lancet; 2018 Mar 17; 391(10125):1023-75.

4. Kim S, Lee J, You D, Jeong Y, Jeon M, Yu J, Kim SW, Nam SJ and Lee JE. (2018). Berberine suppresses cell motility through downregulation

\section{How to cite this article:}

Prabhu Rathnam, K.S.V. and Damodara Reddy, C. 2018. In- vitro Anticancer Activity of Berberine alone and in Combination with Epirubicin on Breast Cancer Cells. Int.J.Curr.Res.Aca.Rev. 6(6), 22-42.

doi: https://doi.org/10.20546/ijcrar.2018.606.004 of TGF- $\beta 1$ in triple negative breast cancer cells. Cellular Physiol Biochem; 45(2):795-807.

5. Tong N, Zhang J, Chen Y, Li Z, Luo Y, Zuo H, Zhao X. Berberine sensitizes mutliple human cancer cells to the anticancer effects of doxorubicin in vitro. Oncol Lett; 2012 Jun; 3(6):1263-1267.

6. Rafehi H, Orlowski C, Georgiadis GT, Ververis K, El-Osta A, Karagiannis TC. Clonogenic assay: adherent cell. J vis Exp. 2011;13(49): pii 2573

7. Ahmadiankia, N., Moghaddam, H. K., Mishan, M. A., Bahrami, A. R., Naderi-Meshkin, H., Bidkhori, H. R., Mirfeyzi, S. J. A. (2016). Berberine suppresses migration of MCF-7 breast cancer cells through down-regulation of chemokine receptors. Iranian Journal of Basic Medical Sciences; 19(2), 125-131.

8. Chou TC. Theoretical basis, experimental design, and computerized simulation of synergism and antagonism in drug combination studies. Pharmacol Rev. 2006 Sep; 58(3):621-81.

9. Balakrishna, A., \& Kumar, M. H. (2015). Evaluation of Synergetic Anticancer Activity of Berberine and Curcumin on Different Models of A549, Hep-G2, MCF-7, Jurkat, and K562 Cell Lines. BioMed Research International; 2015, 354614.

10. Patil JB, Kim J, Jayaprakasha GK. Berberine induces apoptosis in breast cancer cells (MCF-7) through mitochondrial-dependent pathway. Eur J Pharmacol; 2010 Oct 25; 645(1-3):70-8.

11. American cancer society. (Online). 2011; Available from: URL: http://www.cancer.org/

12. Surh, Y., 2003. Cancer chemoprevention with dietary phytochemicals. Nat. Rev. Cancer 3; 768-780.

13. Nobili, S., Lippi, D., Witort, E., Donnini, M., Bausi, L., Mini, E., Capaccioli, S., 2009. Natural compounds for cancer treatment and prevention. Pharmacol. Res. 59; 365-378.

14. Saldanha SN, Tollefsbol TO. The role of nutraceuticals in chemoprevention and chemotherapy and their clinical outcomes. J Oncol; 2012: 1-23. 